بيشبينى تغييرات نقطهاى مقادير نسبى دما و بارش در اثر تغيير اقليم در دورههاى زمانى آينده نزديك و آينده دور و بررسى خشكسالى با استفاده از شاخصهاى SPI و SPEI در دشت قزوين، ايران

سيده مريم بنىهاشمى'، سيد سعيد اسلاميان' و بيزن نظرى '

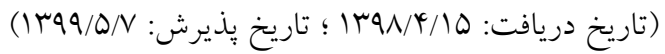

جكيده

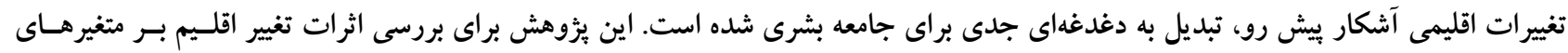

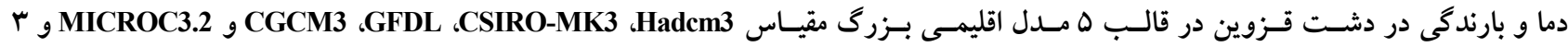

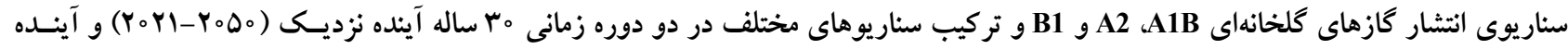

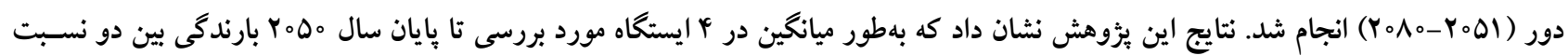

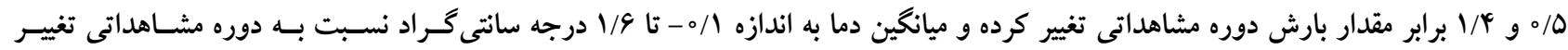

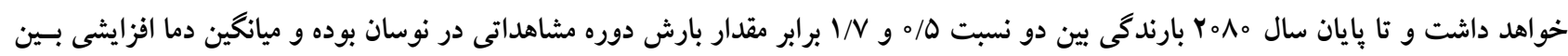

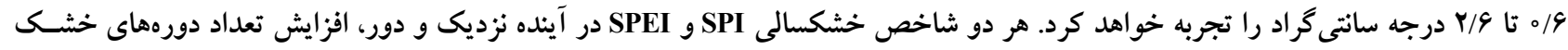

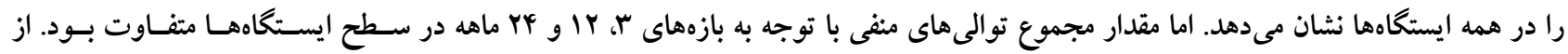

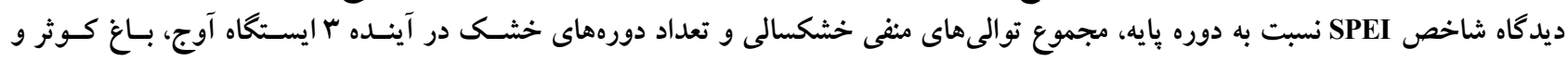

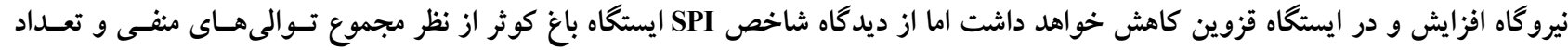

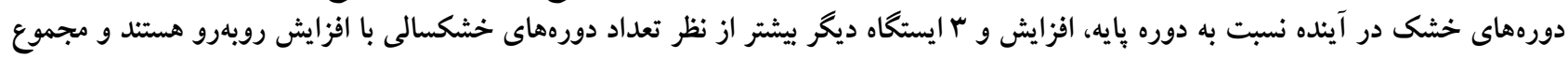

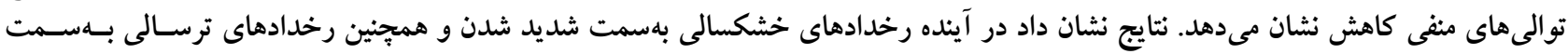

فرين شدن بيش مي مروند.

وازههاى كليدى: تغيير اقليم، دشت قزوين، دما، بارندگى، خشكسالى، شاخص بارش استاندارد شـده (SPI)، شـاخص بــارش و تبخيسر و تعـرق

(SPEI) استاندارد شده:

ا. كروه مهندسى آب، دانشكده كشاورزى، دانشخاه صنعتى اصفهان ז. گروه علوم آب و مهندسى، دانشكده كشاورزى و منابع طبيعى، دانشگاه بين المللى امام خمينى

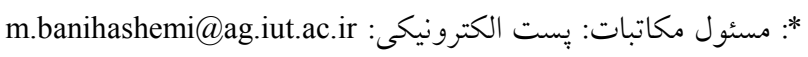


سيستم تصميم گيـرى و برنامـهريـزىهـاى بخـش كشـاورزى،

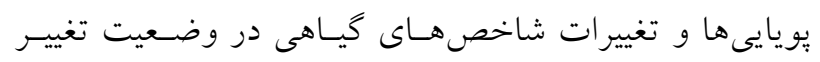

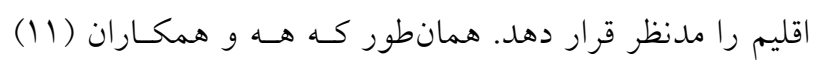

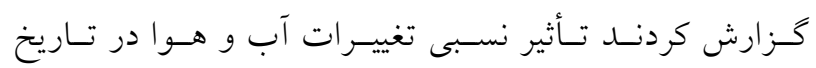

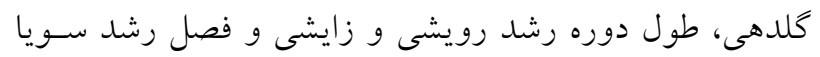

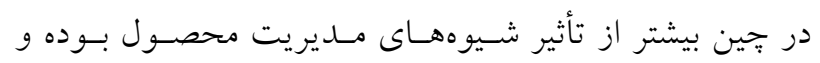

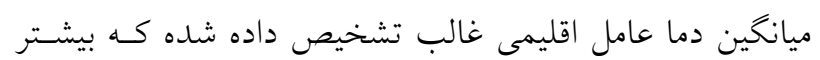

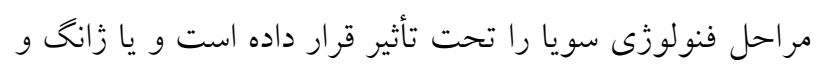

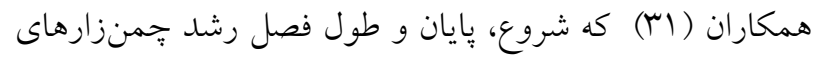

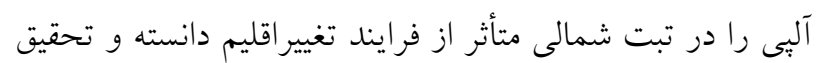
در زمينه تغييرات فنولوزيكى كياهان در اثر تغييــ اقلسيم رالازم

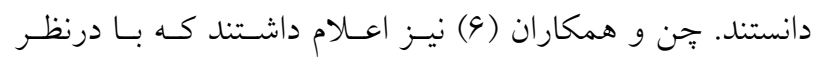
كرفتن برهم كنش كليه تغييـرات اقليمسى و همخجنسين بـا درنظـر كرفتن اثر CO2، در ازاى افزايش يك درجه سانتى گرادى دمـاى

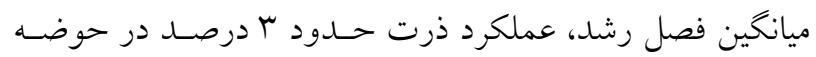

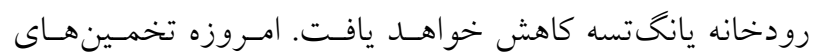

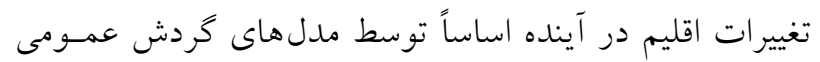

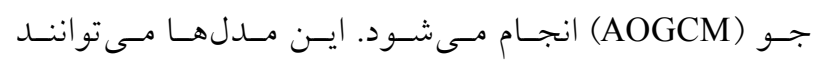

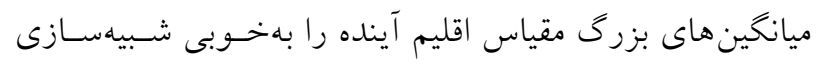
كنند (YO). كزارش جهارم هيأت بين دول تغييي اقليم (IPCC)

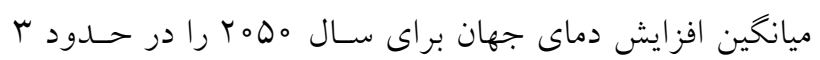

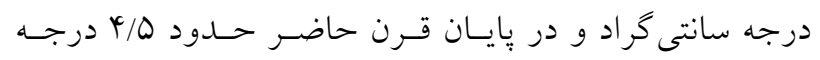

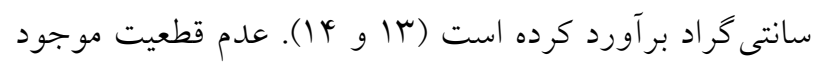

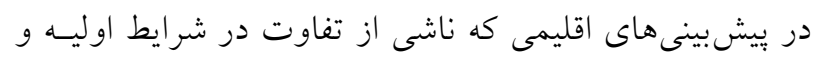

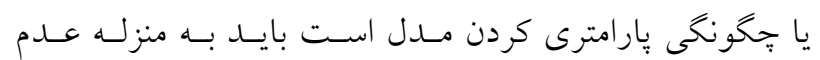

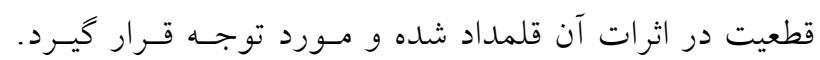

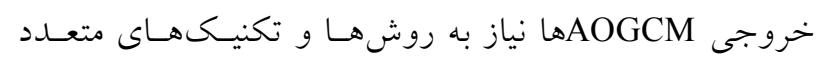
خرد مقياسسازى دارد. يكى از تكنيكهاى خرد مقياس سـازى

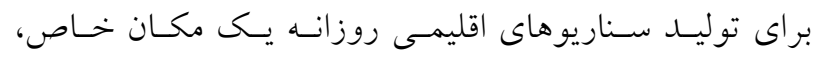
استفاده از مولد آب و هوايى (Weather Generator) تصـادفى براي

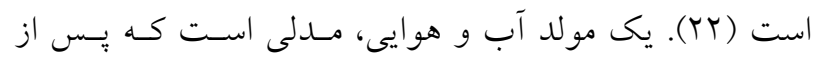

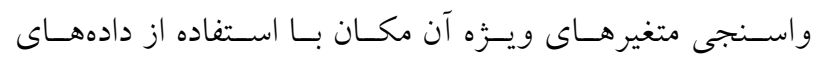

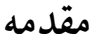

كرمايش جهانى بهعنوان يك حقيقت در سالهاى اخير بذّيرفته

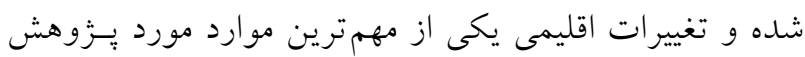

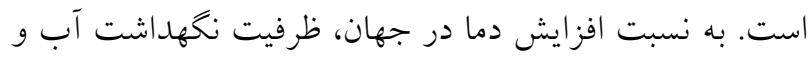

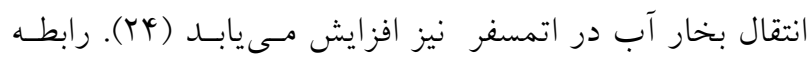

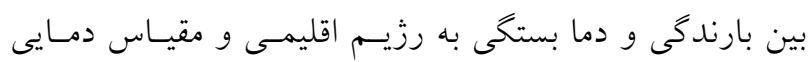

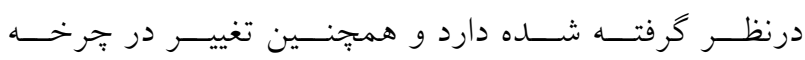

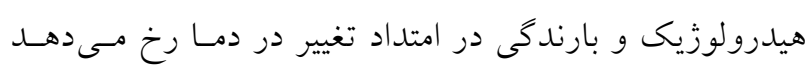
(Y4). گنجايش ترويوسفر براى نخهدارى بخار آب بهازاى هـر

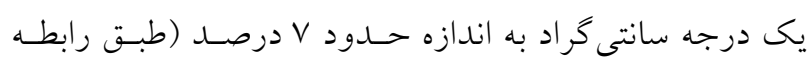

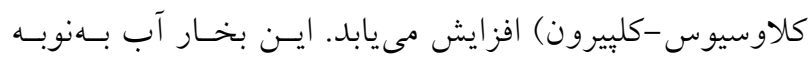

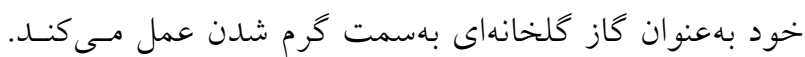

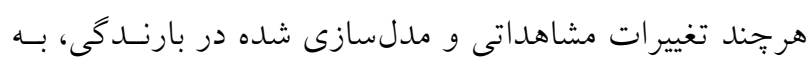
دليل اصل بقاى انرزى (محدود شده بهخاطر در دسترس بودن

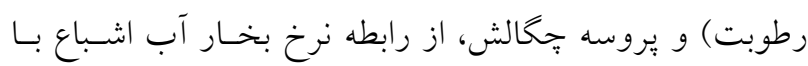

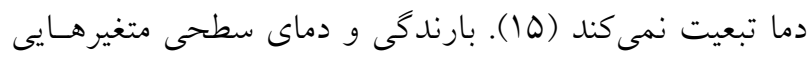

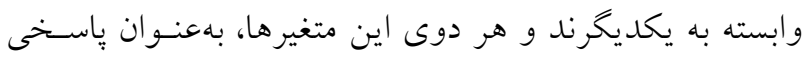
به ديناميك اتمسفر و روابط ترموديناميكى ذاتى آن و بـازخورد

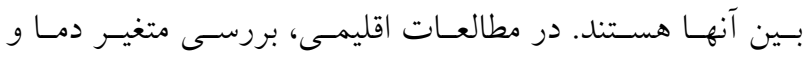

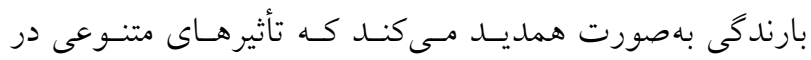
كشاورزى و محيط زيست و همينطور تـأثيرات اجتمـاعى دارد

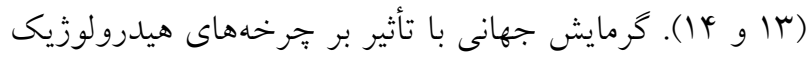

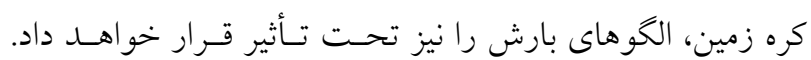

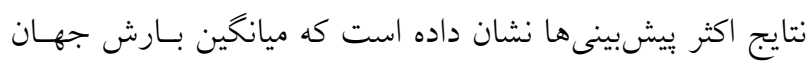
در شرايط اقليمى آينده تا حدودى افزايش مسى يابـد، ولسى ايسن

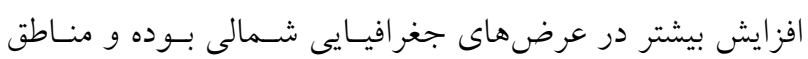
خشى و نيمه خشك جهان با كمبود جلدى بارش مواجه خواهند

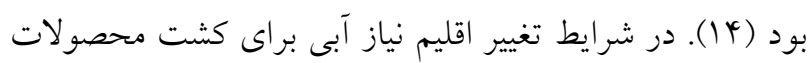

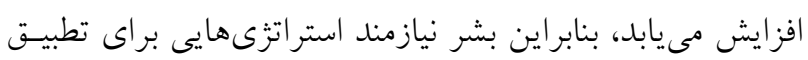

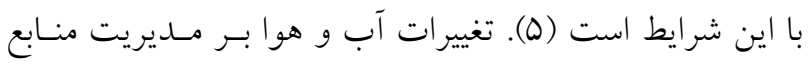

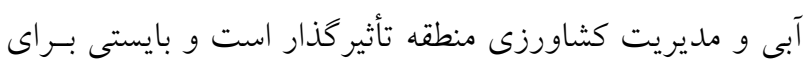

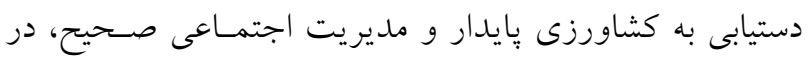




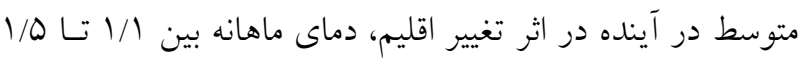

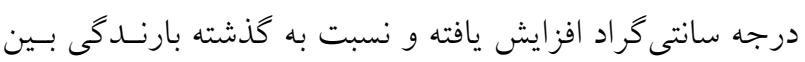
التا اب درصد كاهش خواهد يافت. با توجه بـه حساسـيت و اهميت بديده تغيير اقليم و قرار كرفتن ايران در مـوقعيتى كـه از اين يديده تأثير زيادى خواهد گرفت، لازم است به اين مسئله از زواياى مختلف و به تفكيك هر منطقسه يرداختـهـ شـود كـه ايسن مسئله موضوع يزوهش حاضر است. كشاورزى در دشت قزوين مبتنى بر آب سطحى انتقالى از سد طالقان و آب زيرمينى بوده و در حال حاضر با افت شديد سطح آبخوان روبهرو بوده و نسبت

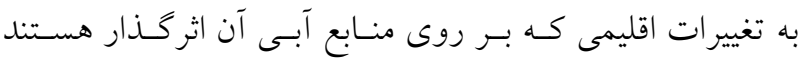
حساس است و لازم است نسبت به شناسايى ايـن تغييـرات در هر مقياسى برداخته شود. در اين بزوهش تغيير اقلسيم در دشـت قزوين بهصسورت جـامع مـورد بررسسى مكـانى قـرار گرفتسه و تغييرات دمايى و بارشى و روند خشكسالى مبتنى بـر بـارش و دما در آينده در سطح تمـامى ايسـتخاههـاى سـينويتيك موجـود بررسى شد.

\section{مواد و روشها - ماد} محدوده مورد مورد مطالعه، اسـتان قـزوين در كشـور ايسران در

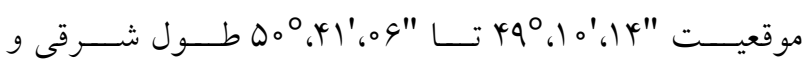

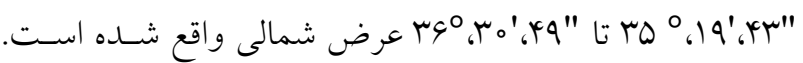

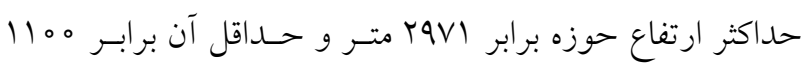
متر از سطح دريا است. مساحت كل حوضه آبريز قـزوين برابـر

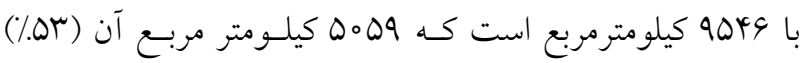

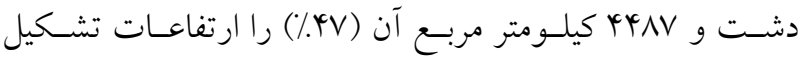
دادهاند. مشخصات ايسـتخاههـاى سـينويتيك اسـتان قـزوين در جدول آآمده است و موقعيت محدوده مورد مطالعـه بـههمـراه ايستخاهها در شكل ا نشان داده شده است. اين ايستخاهها در دوره مشاهداتى مــنظر ايسن يـزَوهش، از آمار تقريباً كاملى برخوردار بوده و دادههـاى گمشــه از طريـق

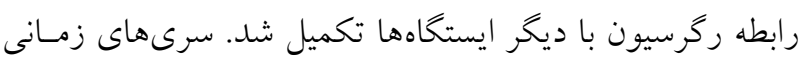

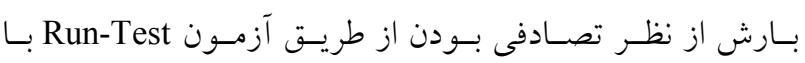

مشاهداتى در ايستخاه مورد بررسى، توانايى شـبيهسـازى سـرى زمانى آب و هواى روزانهاى را خواهد داشت كه از نظر آمـارى اين سرى زمانى روزانه با دادههاى مشاهداتى مشابه باشــند. بـهـ -

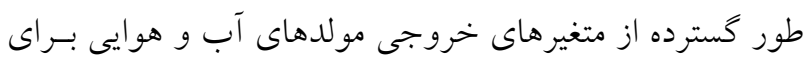
تغييرات اقليمى بيشبينى شده AOGCM بـ براى توليـد سـرى -

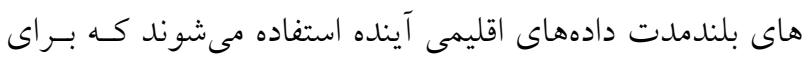
ارزيابى ريسكهاى كشـاورزى و هيـدرولوزيكى مناسـب اسـت

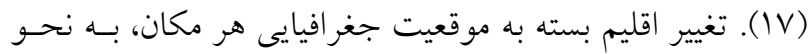

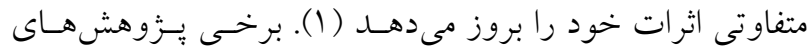
انجام شده براى اثرات تغيير اقلـيم در ايسران و نتــايج كـزارش شده توسط آنها، ماهيت بييجيده و متفاوت تغيير اقليم را در هر

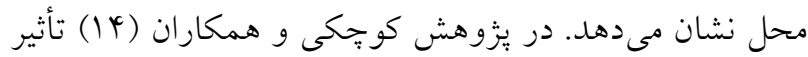
تغيير جهانى اقليم بر شاخصهاى اقليمى كشاورزى ايران بـراى

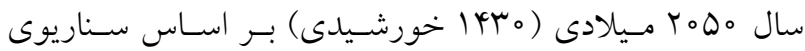
استاندارد IPCC توسط دو مدل گردش عمـومى مـورد ارزيـابى قرار گرفت. نتايج اين بزؤهشخران نشان داد كه ميـانگين دمـاى

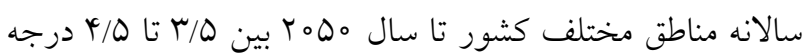
سانتى گراد افزايش مىيابد درحالى كه ميانخين بارش سالانه بين

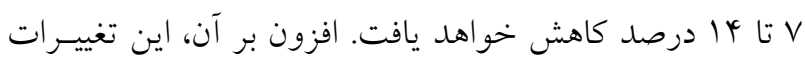
را از غـرب بـه شـرق و از شـمال بـهـ جنـوب كشـور شـــيدتر بيشبينى كردنـد. بابائيـان و كـوهى (T) ميـزان افـزايش دمـا در انتهاى قـرن حاضـر در ايسـتخاههــاى مشـهل، سـبزوار و تربـتـ

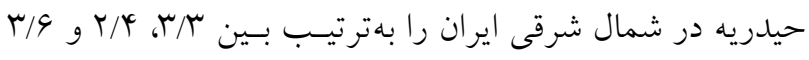

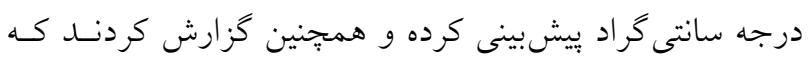

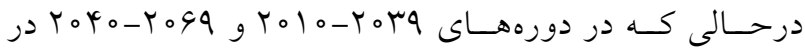
ايستخاه تربت حيدريه و سبزوار افزايش بارش بيش بينى شـده است اما در همين دوره ايستخاه مشههد شـاهد كـاهش بـارش نسبت به دوره يايه خواهد بود و نتايج مدلسازى در رابطه بـا كاهش بارش در سومين دوره مدلسازى 990-roو ايستخاه با هم هماهنخ بـوده و در هـر سـه ايستخاه كاهشى است. كوهرى و همكــاران (0 (1) در بررسـى دشـت رودخانـه زايندهرود ايران (مركز ايران) به اين نتيجه رسـيدند كـه بـهــور 
جدول ا. مشخصات ايستخاههاى سينويتيك محدوده طرح

\begin{tabular}{|c|c|c|c|c|c|}
\hline عرض جغر افيايى & طول جغرافيايى & ارتفاع (متر) & نوع ايستخاه & دورة آمارى & ن ام ايستخاه \\
\hline Yo००ᄉाr & $r r V \circ r q / q$ & $1 r V q / r$ & سينويتيك & $r 010-1909$ & قزوين \\
\hline rarkruga & $m q_{0} 10 / v$ & $r \circ r y / q$ & سينويتيك & roo9-1999 & 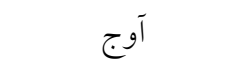 \\
\hline Y०YNDIT & FYIVIr/q & ITTO & سينويتيك & 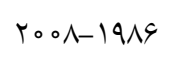 & باغ كوثر \\
\hline T৭9GYAN & FTrYqV/T & $I T \wedge D$ & سينويتيك & Yo०^-19^4 & نيرو كاه شهيد رجايى \\
\hline
\end{tabular}

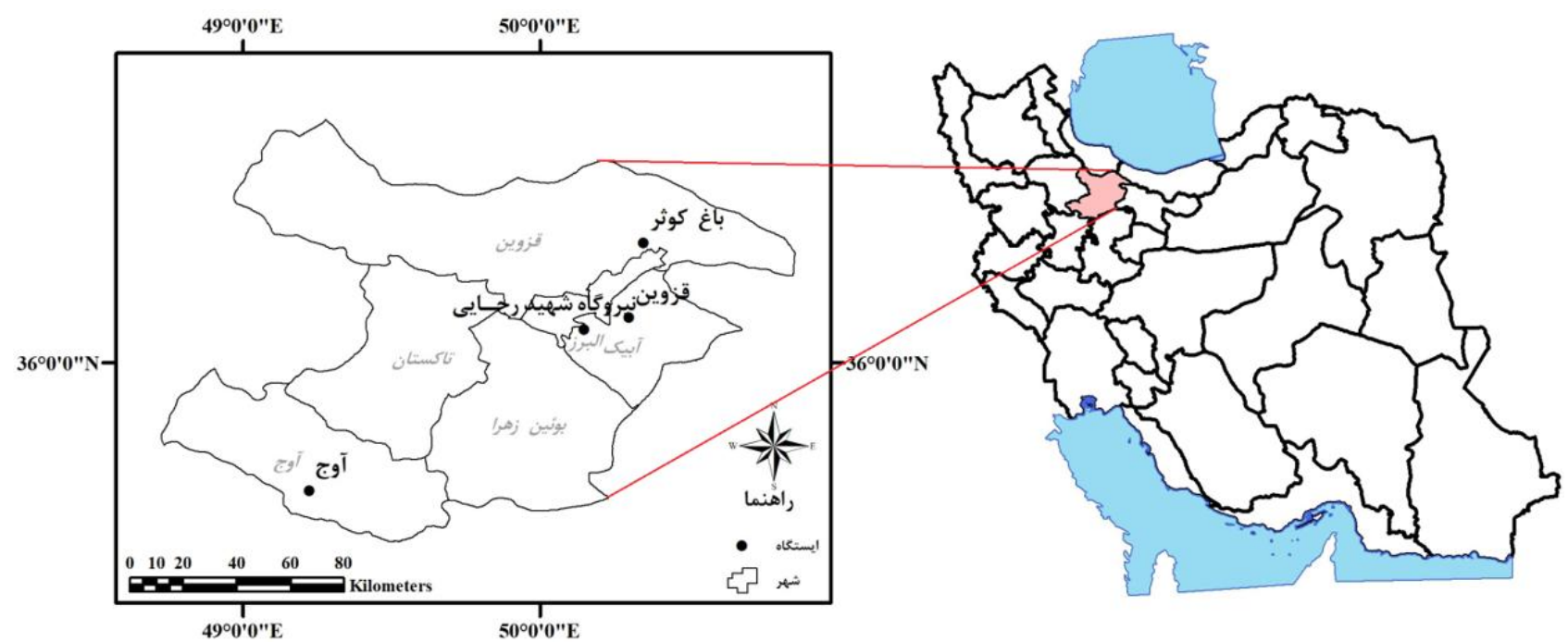

شكل ا. موقعيت استان قزوين بههمراه ايستخاههاى سينويتيك مورد مطالعه

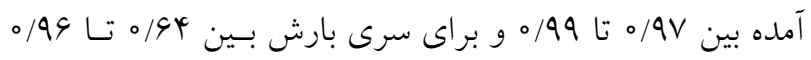

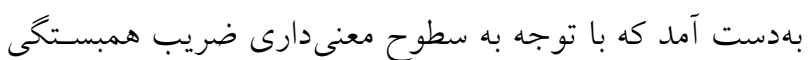
اين مقادير معنى دار و نتايج قابـل قبـول اسـت. سـناريوهاى R2 انتشار مورد استفاده در ايسن يـزوهش سـناريوهاى A1B،

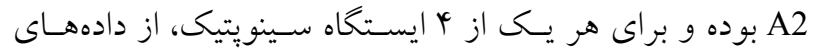
بزرگ مقياس شامل ميانخين هـاى دمـاى بيشـينه، دمـاى كمينـه،

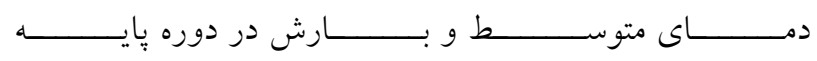

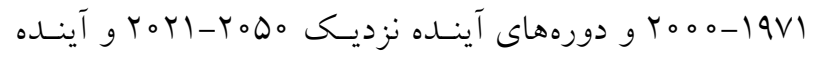

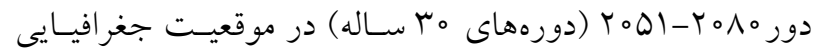

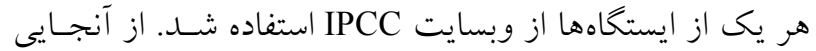
كه هر يك از اين AهOACM در قالب يـك سـلول بأنقطـهاى ميانخين هاى بزرگمقياس متغيرهاى اقليمى را مورد بررسى مسى
نرمافزار SPSS و از نظر همخن بودن از طريق رسم منحنى جرم مضاعف مورد بررسى و تأييد قرار كرفت.

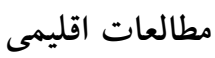

در اين يزووهش از مدلهـاى اقليمسى Hadcm3، CSIRO-MK3،

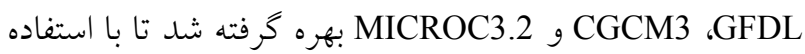
از ميانخين خروجى اين مدلها بتوان به اجماع نظر و ديد كاملى

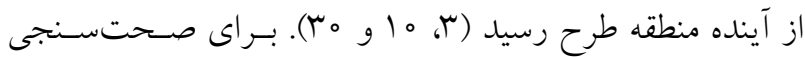
شبيهسازى انجام شده توسط مدلهاى اقليمى، بـين سـرى شسبيه سازى شده دما و بارش در دوره مشـاهداتى و سـرى دادههـاى مشاهداتى در تمام ايستخاهها خط رگرسيون بـرازش داده شـد و و در مورد سرى دما در تمام ايستخاهها، ضريب همبستخى بهدست 


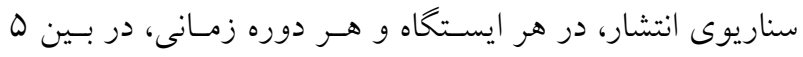

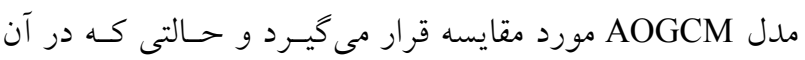

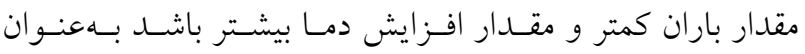

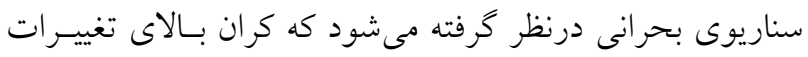

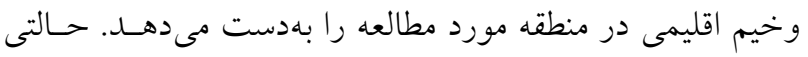

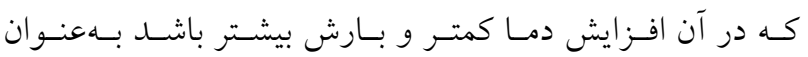

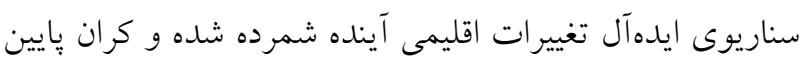

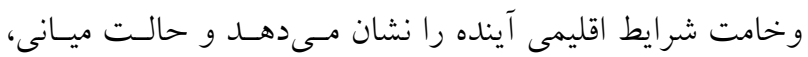
شر ايطى بين اين دو حالت را دارد (r). بـه ايسن ترتيسب نسـبت

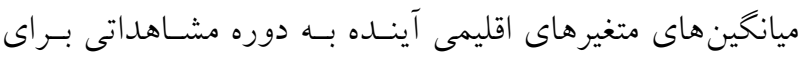

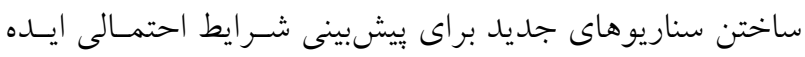

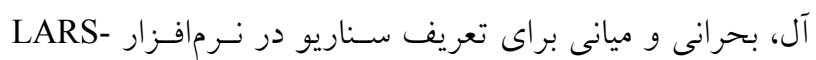

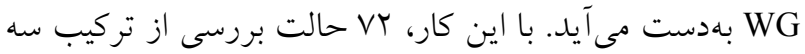

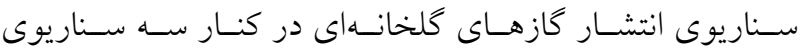
احتمالاتى (از تركيب احتمال وقوع هر يكى از مقادير متغيرهـاى

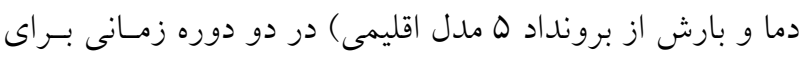

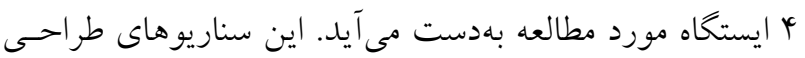

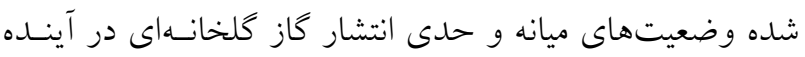

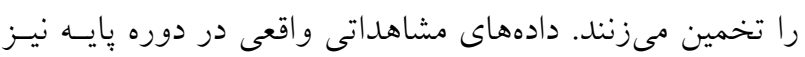

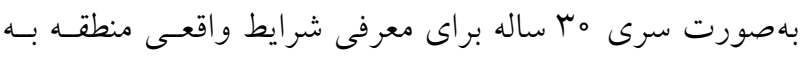

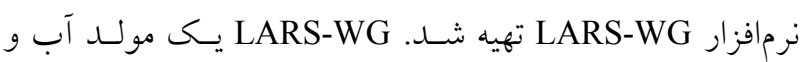
هوايى تصادفى است كه دادههاى اقليمى آينـده را از روى داده-

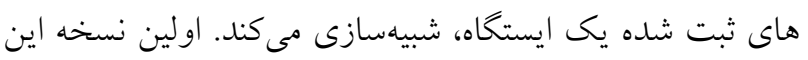

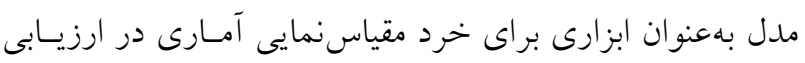

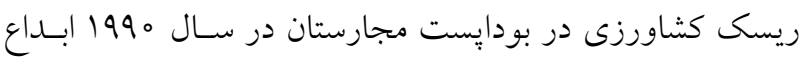

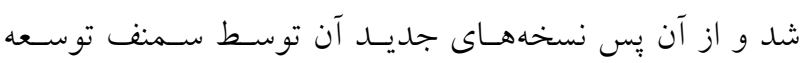

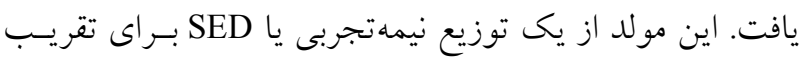

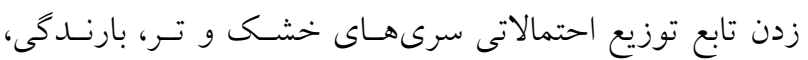

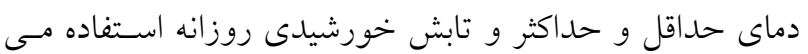

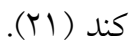
خروجى ها شامل سرى دادههاى دماى بيشينه، دمـاى كمينـه،

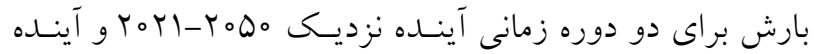

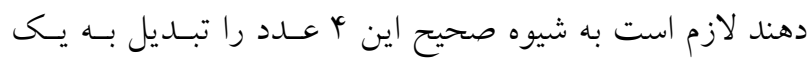

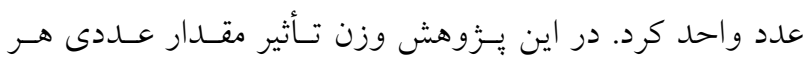

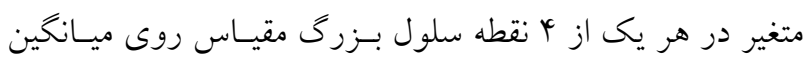
همان متغير در موقعيت هر ايستخاه بـهـ نسـبت فاصـلهاى كـهـ از

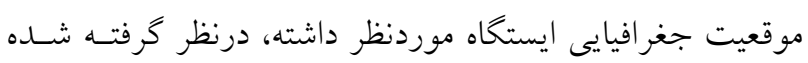

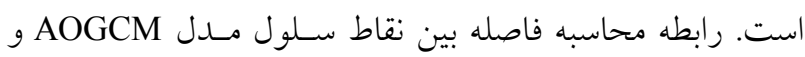

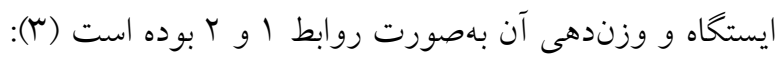

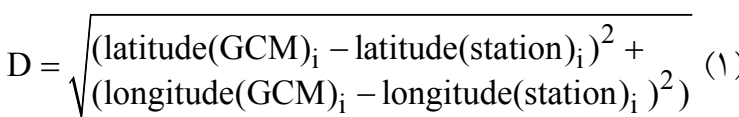

Tmean $=\frac{\text { T GCM } \mathrm{i} \times \frac{1}{\mathrm{Di}}}{\sum \frac{1}{\mathrm{Di}}}$

كه در آن D مقدار فاصسله و T وزن تـأثير هـر يـك از ب نقطسه سلول متغيرهاى اقليمى بزرگمقياس است. با اين روش مقــادير

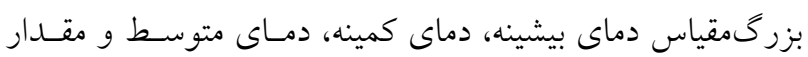

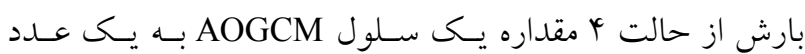
واحد تبديل شدند. اين كار بـراى تمـام AOتهـا در تمـام سناريوهاى انتشار كاز

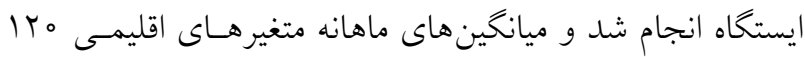

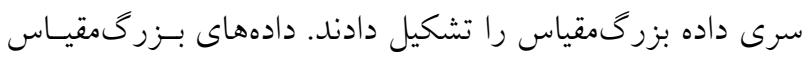

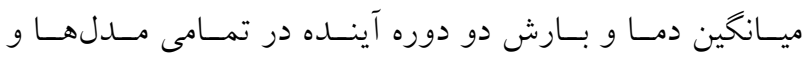
سناريوهاى انتشار با همان دادهها در دوره مشـاهداتى در همـان

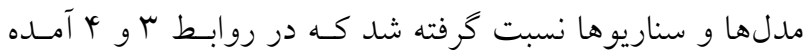

$\Delta \mathrm{T}=\mathrm{T}_{\text {future }}-\mathrm{T}_{\text {base }}$

$\Delta \mathrm{P}=\frac{\mathrm{P} \text { future }}{\mathrm{P} \text { base }}$

كه در آن هT، مقدار تغييرات ميـانخين دمـاى بـزرخمقيـاس در

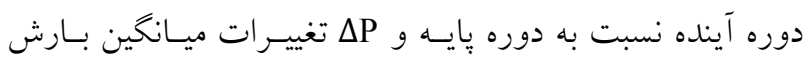

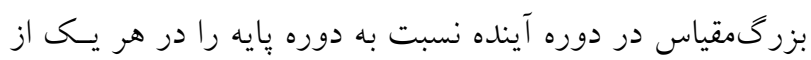

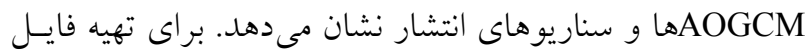

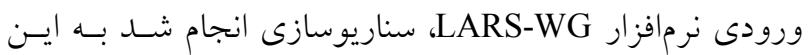

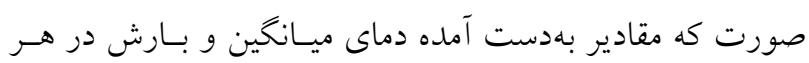


شاخص SPI از تابع جگالى توزيع گاما و كاهى از تابع بيرسون

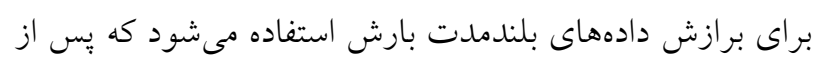

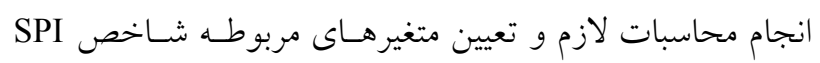

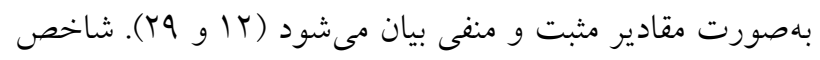

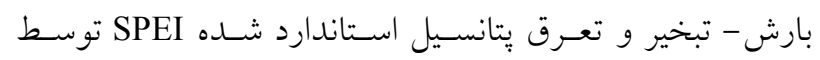

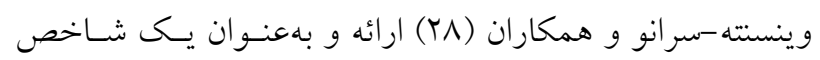

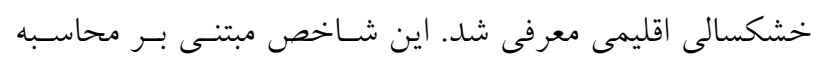

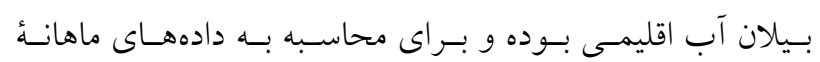

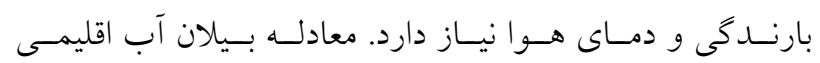

$$
\text { باصورت زير است: }
$$

$\mathrm{D}=\mathrm{P}_{\mathrm{i}}-\mathrm{PET}_{\mathrm{i}}$

كه درآن P و PET بهترتيب بارندگى و تبخير و تعرق پتانسـيل،

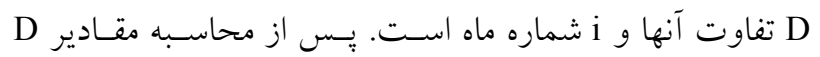

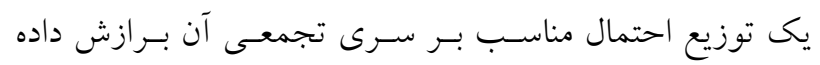

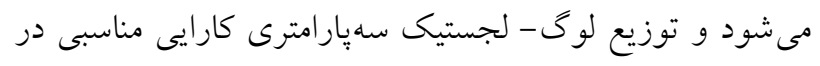

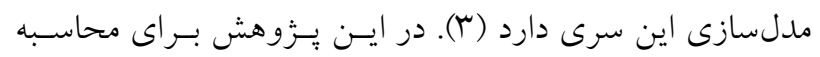

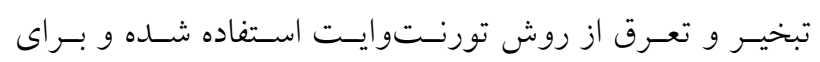

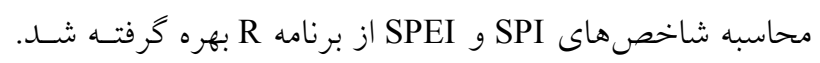

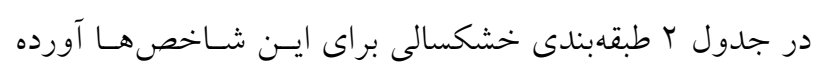
شده است.

\section{نتايج و بحث}

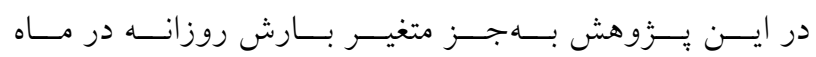

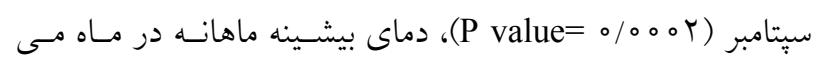
و دسـامبر (P value = o/009)

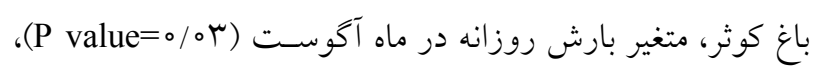

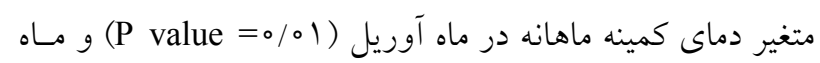

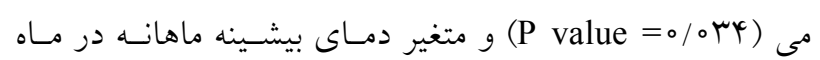

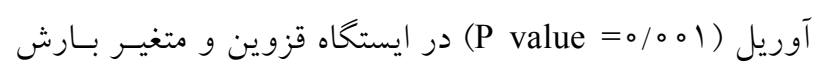

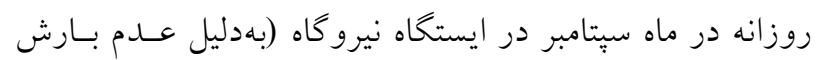

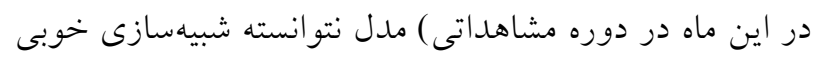

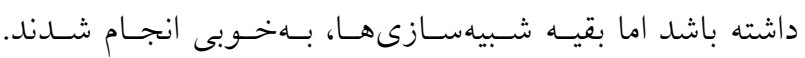

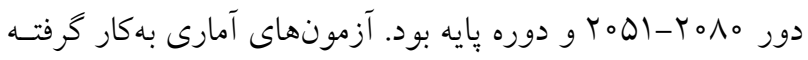

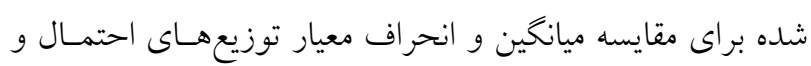
ارزيابى قابليت مدل، آزمون كلمو گروف اسميرنوف (براى آزمودن آتحري

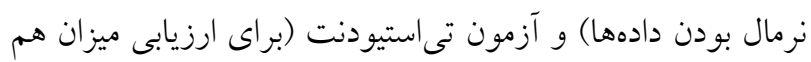

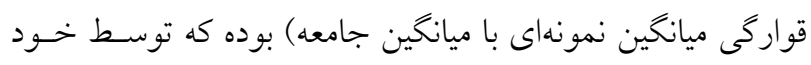

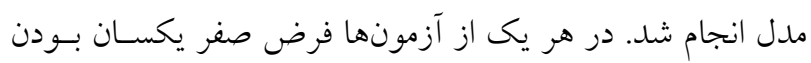

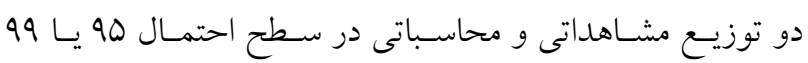

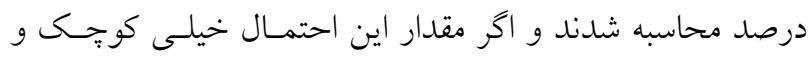

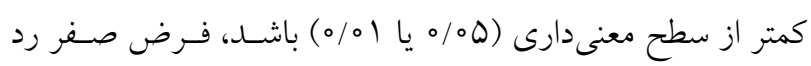

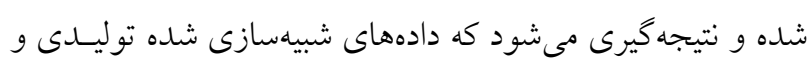
دادههاى واقعى از نظر آمارى يكسان نيستند (V).

\section{شاخص خشكسالى SPI و SPEI}

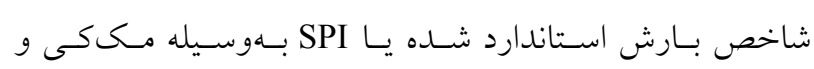

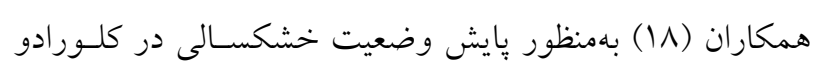

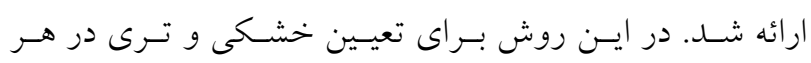

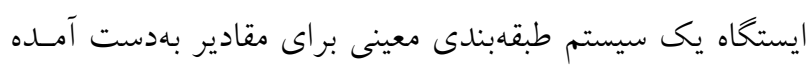

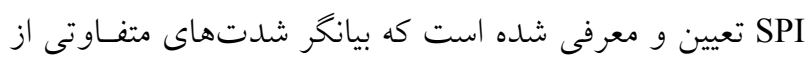

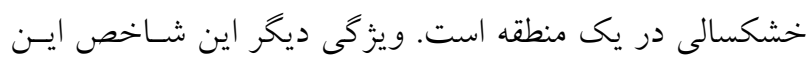

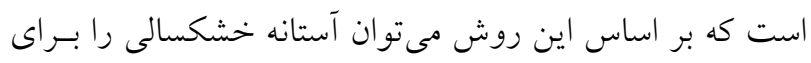

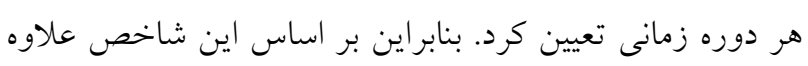

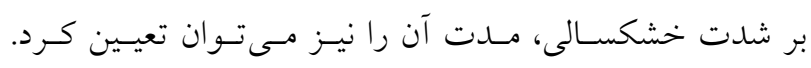

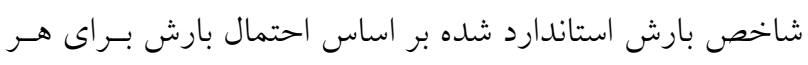

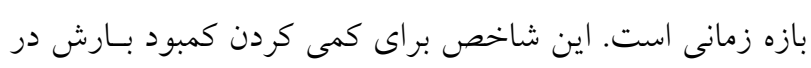

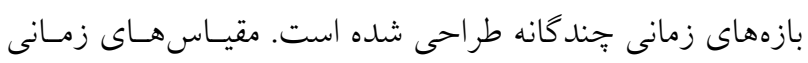

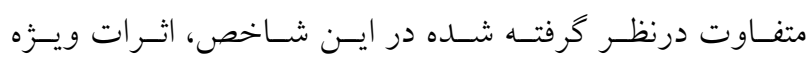
خشكسالى را روى قابليت دسترسى به منابع آبسى مختلـف بيـان

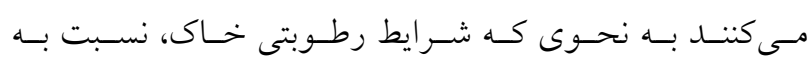

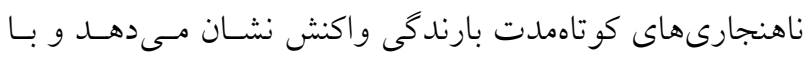

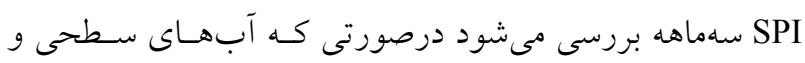

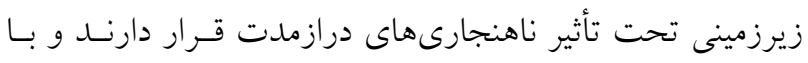
SLPI 
جدول r. ضرايب شاخص خشكسالى SPI و SPEI

\begin{tabular}{|c|c|c|c|}
\hline مقادير SPI و SPEI & فراوانى تجمعى (درصد) & & \\
\hline r & كمتر از س/ & فرين & \\
\hline -1/0。 ا 1/99 & 9/V & شديد & خشكسالى \\
\hline q 1/1 تا 1- & 11 9/9/9 10/ & متوسط & \\
\hline ه/99 ت ا & 19 تا Nr/9 & 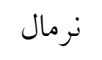 & \\
\hline اتا 1/49 & N & متوسط & \\
\hline 1/99 1/هـ تا & qV/V & 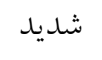 & ترسالى \\
\hline r و بيشتر & بيش از QV/V & فرين & \\
\hline
\end{tabular}

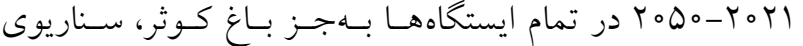
تركيبى A2 ايدهآل و فقط در ايستخاه باغ كوثر سناريوى تركيبى ايدهآل، بيشترين افزايش نسبت بارندگى را كه بـالاى A1B برابر نسبت به دوره مشاهداتى بـوده اسـت را يسيشبينى كـرده است و سناريوى تركيبى A1B بحرانى بيشترين ميـزان تغييـرات كاهشى بارندگى كه در حدود نصـف دوره مشـاهداتى بـوده را

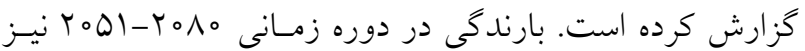
در تمام ايستخاهها، در سـناريوى تركيبى A2 ايـدهآل، بيشـترين افزايش نسبت بارندگى را كه در حدود V/ برابر نسبت به دوره مشاهداتى بوده است را ييشبينى كرده و بيشترين ميزان تغييرات كاهشى بارندگى در تمام ايستخاهها در سـناريوى تركيبى A1B بحرانى و A2 بحرانى بوده كه ايسن مقــدار كـاهش بارنـدگى در حدود نصف دوره مشاهداتى بوده است. بنـا بـر مـدلســازى و و

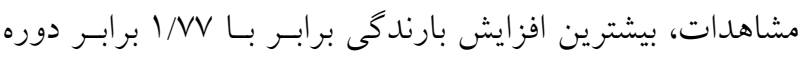
A2 مشاهداتى در دوره زمانى •N॰

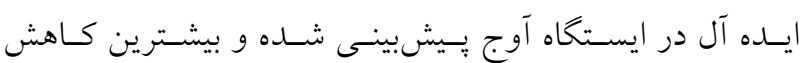
بارندكى نيز برابر با و4ه/ مقدار دوره مشاهداتى در دوره زمـانى

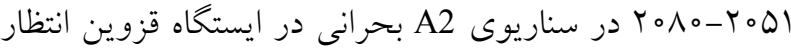

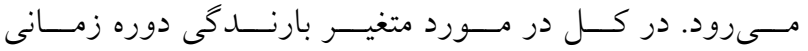

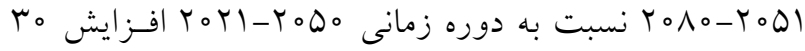

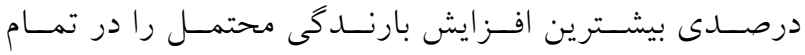
سناريوهاى تركيبى نسبت به دوره مشاهداتى نشـان مسىدهـــ.

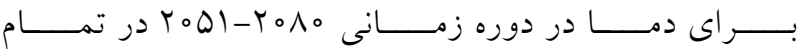

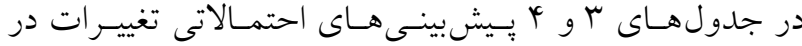
سناريوهاى تركيبى مختلف از دو متغير اقليمى دما و بارش در ب ايستخاه در سطح استان قـزوين در دو دوره زمـانى مباسـاله تـا

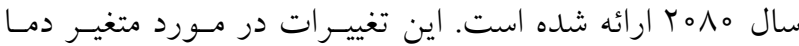
بهصورت تغييرات مطلق نسبت به دوره مشاهداتى كزارش شده و براى متغير بارش بهصورت نسبى، نسبت بـه دوره مشـاهداتى

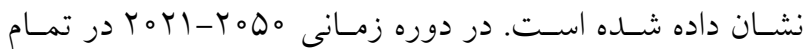
ايستخاهها براى متغير بارش، در كمترين حالت يِيشبينى شده از

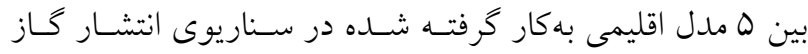
كلخانهاى A1B، نسبت بارندگى دوره آينده به دوره مشـاهداتى برابر بـا ساه/ه بـودهه و در بيشـترين حالـت يسيشبينس شــده در سناريوى انتشار كاز كلخانهاى A2، در ايستخاه آوج اين نسـبت به 1/Y أمىرسد. همجنين متغير دما در بين ه مدل اقليمسى نـام برده در دوره •D०

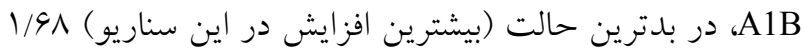
درجه سانتى گــراد افـزايش نشـان داده و در بهتـرين حالـت ايدهآل از بين ه مدل اقليمى /1/ه - درجه سـانتى گـراد كـاهش نشان داده است. در همه ايستخاهها در هر دو دوره زمانى، مقدار متغير بارش در سناريوى ايسـدآل در حالـت بيشـينه خــود از دو سناريوى ميانخين و بحرانى به نسبت دوره مشاهداتى بيشتر بوده و متغير دما در سناريوى ايدهآل، كمترين ميزان افـزايش خــود را نسبت بـه دوره مشـاهداتى بـه نسـبت دو سـناريوى ميـانخين و بحرانى تجربه كـرده اسـت. در متغيـر بارنسدگى در دوره زمـانى 
جدول ب. ميزان نسبت تغييرات دما و بارندگى در سناريوهاى مختلف در ايستخاههاى مورد بررسى در

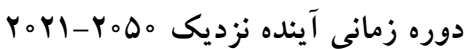

\begin{tabular}{|c|c|c|c|c|c|c|c|c|c|c|c|c|c|c|c|c|c|}
\hline \multicolumn{6}{|c|}{ بارندكى } & \multicolumn{12}{|c|}{ دما } \\
\hline \multicolumn{2}{|c|}{ آوج } & \multicolumn{2}{|c|}{ قزوين } & \multicolumn{2}{|c|}{ باغ كوثر } & \multicolumn{2}{|c|}{ نيرو كاه } & \multicolumn{2}{|c|}{ آوج } & \multicolumn{2}{|c|}{ قزوين } & \multicolumn{2}{|c|}{ باغ كوثر } & \multicolumn{2}{|c|}{ نيرو كاه } & \multirow{2}{*}{\multicolumn{2}{|c|}{ سناريوهاه }} \\
\hline بيشينه & كمينه & بيشينه & كمينه & بيشينه & كمينه & بيشينه & كمينه & بيشينه & كمينه & بيشينه & كمينه & بيشينه & كمينه & بيشينه & كمينه & & \\
\hline.$/ 90$ & - /Qr & $0 / 94$ & - /Qr & ०/9T & $\circ / \Delta V$ & $0 / 94$ & $\circ / \Delta Q$ & $1 / 91$ & $0 / 91$ & $1 / 09$ & $0 / 9 \mathrm{~V}$ & $1 / 4 k$ & $\circ / \Lambda \Lambda$ & $1 / \Delta r$ &.$/ 94$ & بحرانى & A1B \\
\hline س $1 / 1$ &.$/ 90$ & $1 / 41$ & $0 / 99$ & $1 / 41$ &.$/ 99$ & $1 / \pi V$ &.$/ 99$ & $1 / 11$ & ه & $1 / 1 r$ & & $1 / 04$ & سת/ס & $1 / 09$ & O/MY & ايده آل & A1B \\
\hline $1 / \circ 0$ & $0 / 19$ & $1 / \circ 0$ & $\circ / M$ & $1 / 04$ & -/M & $1 / 0 \mu^{4}$ & $\circ / \wedge 9$ & $1 / \Lambda \Lambda$ & o/VG & $1 / 79$ & $\circ / V Y$ & $1 / 11$ & $0 / 99$ & $1 / r y$ & $\circ / V_{1}$ & ميانخين & A1B \\
\hline $0 / 91$ & $0 / 9 \pi$ &.$/ 99$ & $0 / 94$ & $0 / 99$ & $0 / 90$ & $0 / 99$ & $0 / 94$ & $1 / \Delta V$ & $0 / 9 \mathrm{~V}$ & $1 / 40$ & $0 / 9 \mathrm{~V}$ & $1 / / \mu T$ & $0 / 91$ & $1 / \pi 4$ & $0 / 94$ & بحر انى & $\mathrm{A} 2$ \\
\hline $1 / 4 v$ & $0 / 99$ & $1 / 4 \pi$ & 1 & $1 / T^{4}$ & 1 & $|/ 4|$ & $0 / 99$ & $1 / 11$ & DMT & $1 / 09$ & $\circ / \mu \wedge$ & $0 / 9 \mathrm{~V}$ & $0 / \mu Y$ & $1 / 0 Y$ & $0 / M V$ & ايده آل & A2 \\
\hline$M / T$ & $\circ / 19$ & $1 / 00$ & $0 / 91$ & $1 / 00$ & $0 / 91$ & $1 / 00$ & $0 / 9$ & $1 / \pi 9$ & $\circ / \Delta V$ & $|/ r|$ & $\circ / \Delta \Delta$ & $1 / 11$ & $0 / 01$ & $1 / I V$ & . & ميانگين & $\mathrm{A} 2$ \\
\hline.$/ 91$ &.$/ 09$ & $0 / 9 V$ &.$/ 09$ & $\circ / 9 \mathrm{~V}$ &.$/ 09$ & $0 / 9 V$ & $\circ / \Delta \Lambda$ & $1 / N y$ & $\circ / V Q$ & $1 / T Y$ & $\circ / N r$ & $1 / 1 \pi$ & $0 / 9 \mathrm{~V}$ & $1 / 19$ & $\circ / N 1$ & بحر انى & $\mathrm{B} 1$ \\
\hline $1 / 19$ & $1 / 01$ & $1 / \pi r$ & $1 / 0 r$ & $|/ T|$ & $1 / 0 r$ & $|/ T|$ & $1 / 04$ &.$/ 90$ & $-0 / 09$ & O/AY & $-0 / 11$ & $\circ / N$ & $-0 / 09$ & $0 / \Lambda \mid$ & $-0 / 09$ & ايده آل & $\mathrm{B} 1$ \\
\hline $1 / 00$ & O/NK & $1 / 00$ & - & $1 / \circ 0$ & -/NF & $1 / 00$ & - /NFV & $1 / 1 r$ & $0 / 91$ & $1 / 09$ & $\circ / \Delta V$ & $0 / 99$ & - /Qr & $1 / 00$ & $\circ / \Delta 0$ & ميانخين & B1 \\
\hline $1 / 4 V$ & ./QR & $1 / 4 \pi$ & - & $1 / 41$ & $\circ / \Delta V$ & $|/ 4|$ &.$/ \Delta \Delta$ & $1 / 91$ & $-0 / 09$ & $1 / 09$ & $-0 / 11$ & $1 / 44$ & $-0 / 09$ & $1 / \Delta r$ & $-0 / 09$ & كل & \\
\hline
\end{tabular}

جدول fا. ميزان نسبت تغييرات دما و بارندگى در سناريوهاى مختلف در ايستخاههاى مورد بررسى در

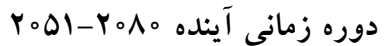

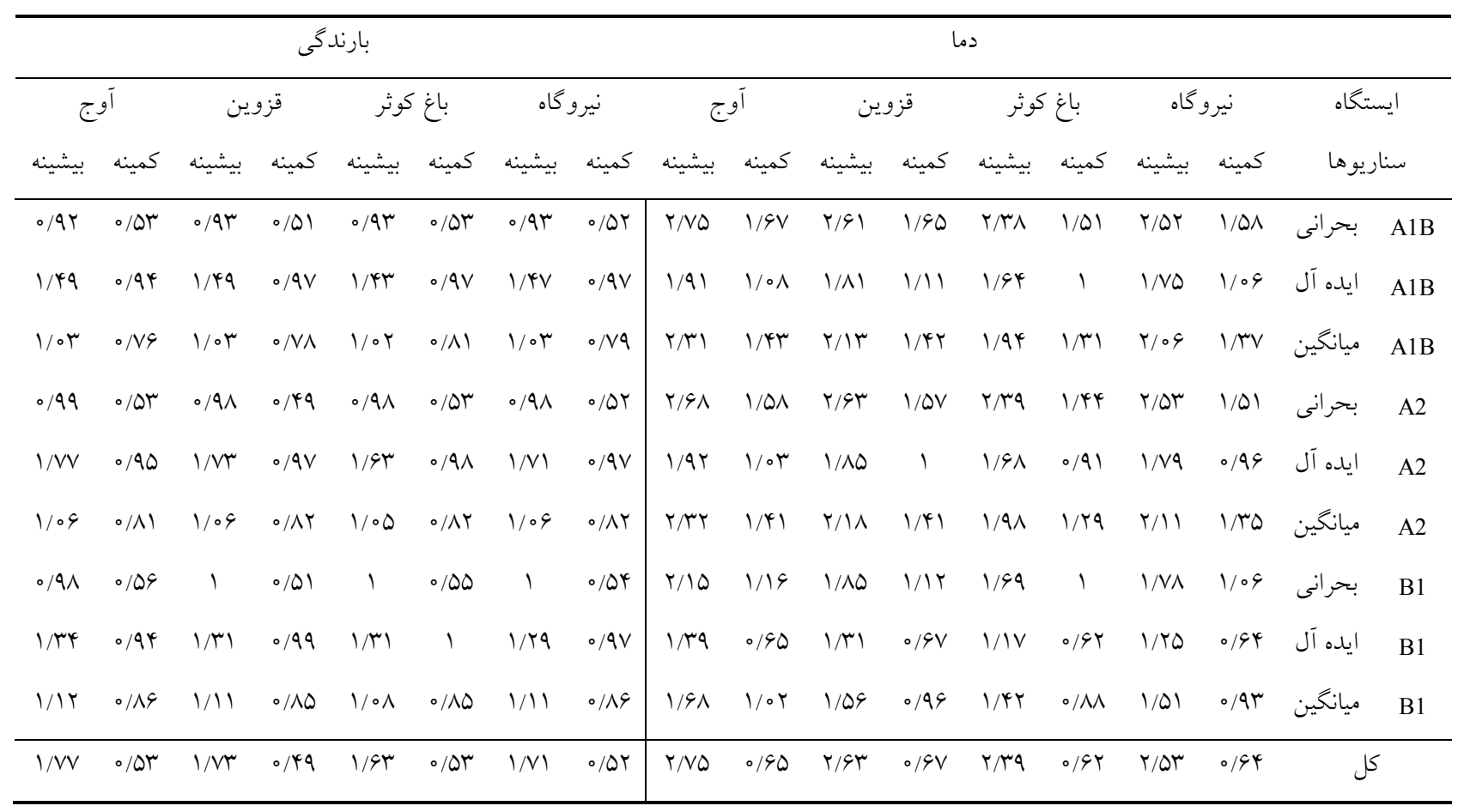




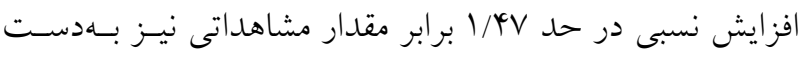

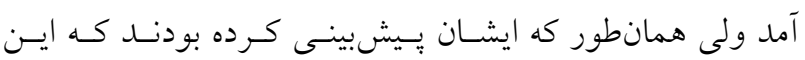
تغييرات از غرب به شرق و از شمال به جنوب كشـور شـديدتر

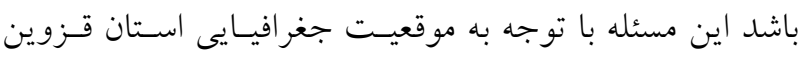
همخوانى دارد. نتايج اين يزوهش مطابق نتايج :ـرزوهش بابائيسان و كوهى (Y) است كه ييشبينى كردند كه در انتهاى قرن حاضـر

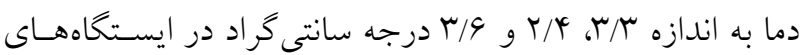

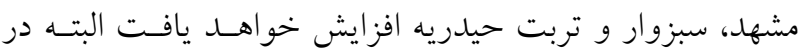
ايستخاههاى مـورد بررسى در دشـت قـزوين ايـن افـزايش در بيشترين حالت خود بهاندازه T/VD درجه سانتى گراد در ايستخاه

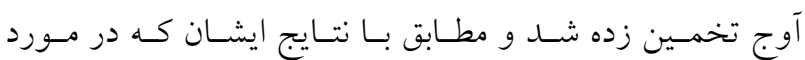

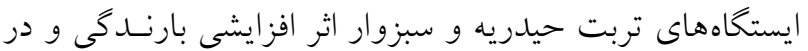

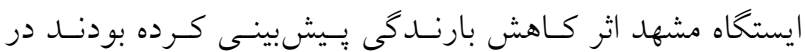

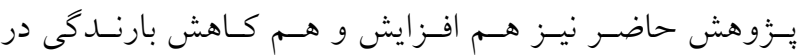

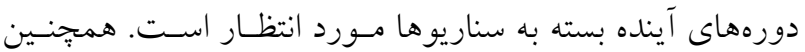
همانكونه كه كوهرى و همكاران (0 1) در دشت رودخانه زاينده

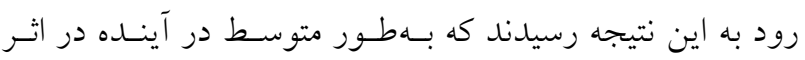

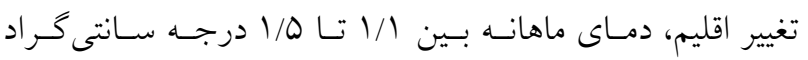

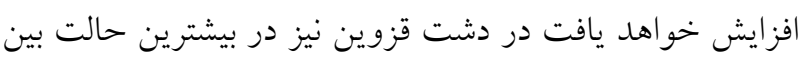

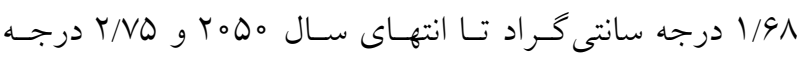

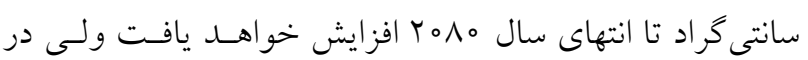

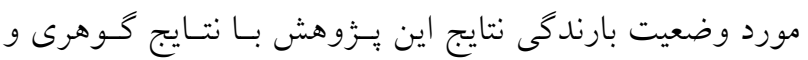

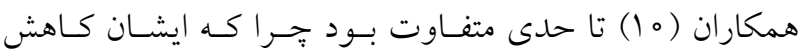

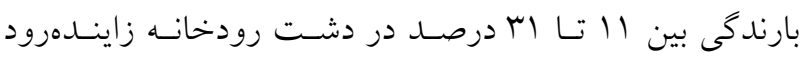

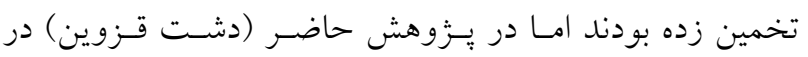

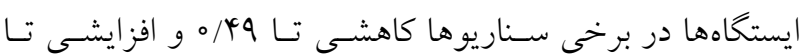

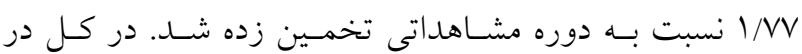
يززوهش حاضر دما روندى افزايشى را نشان داده اما بارش مانند دما الكوى مشخصى نداشته است. ييشبينى افزايش بارندگى در إنى

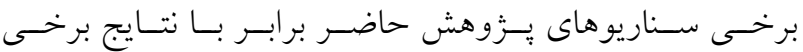

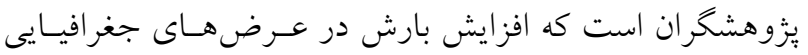

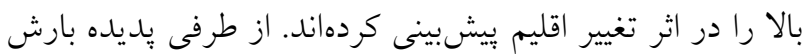

A2 بحر ايستحى و سـناريوى در سناريوى تركيبى

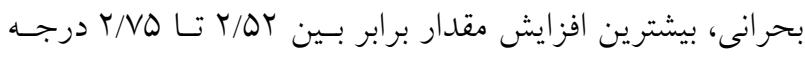

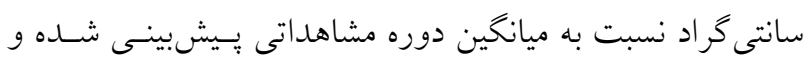

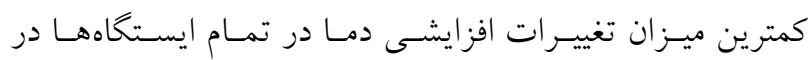

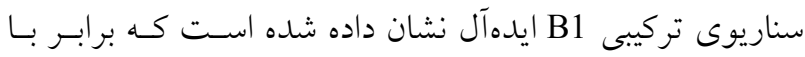

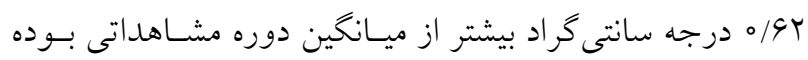
است. بنا بر يززوهش انجام شده، بيشترين افزايش دما در ايستخاه

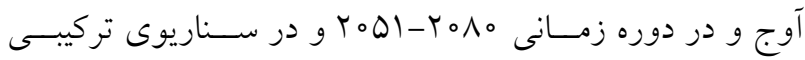

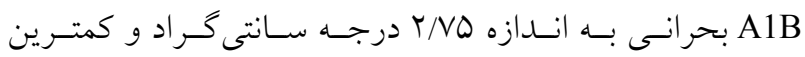

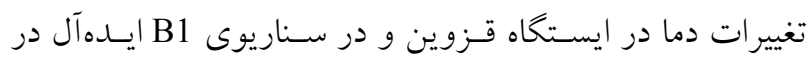
دوره زمانى •

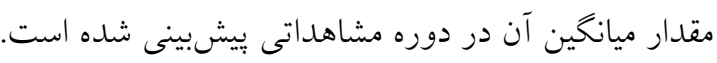

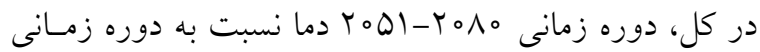

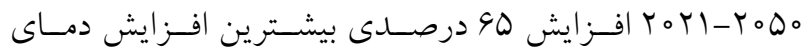

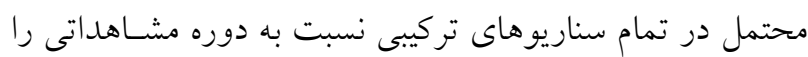

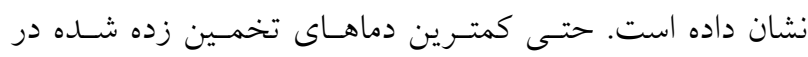

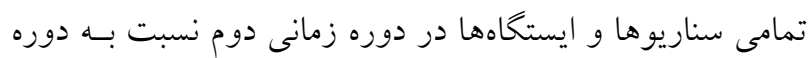

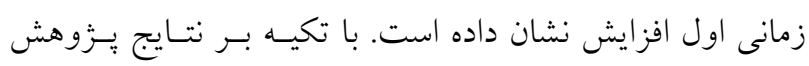

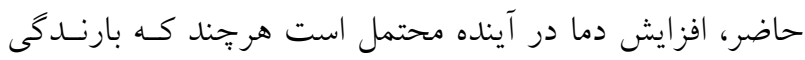

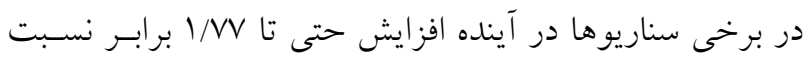
به دوره مشاهداتى را نشان مىدهد از طرفى در برخى ســناريوها

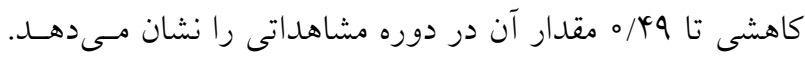

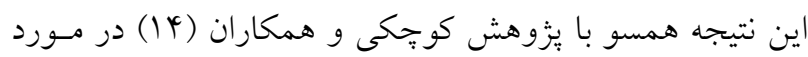

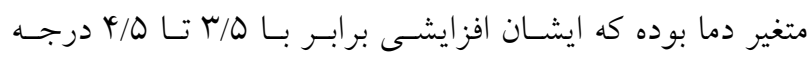

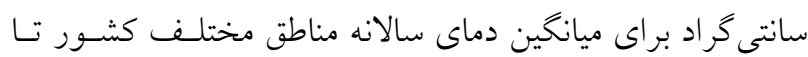

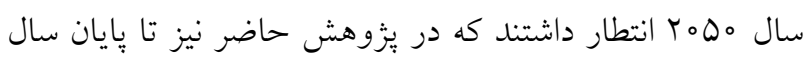

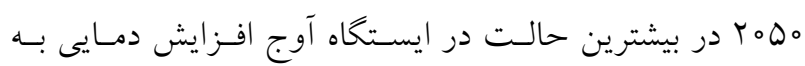

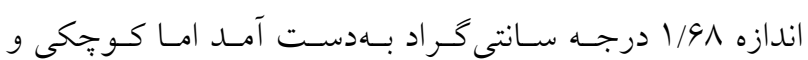

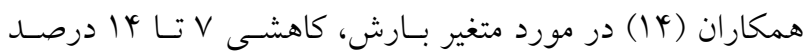

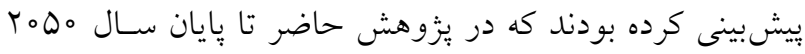

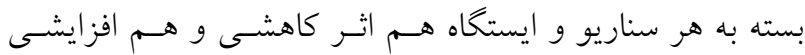

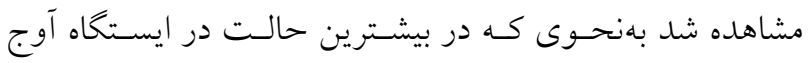


بلندمدت، كاهش نشان داده و فقط در مـورد ايستشاه نيروگــاه در

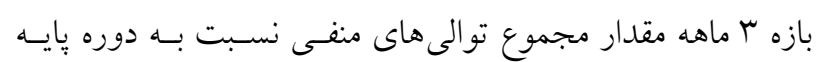

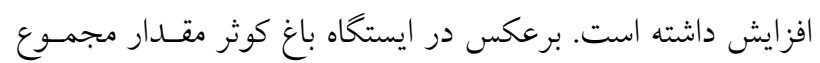

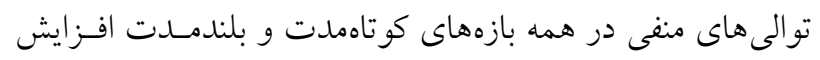

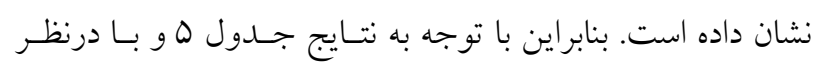

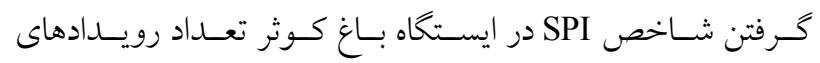

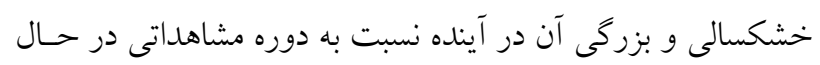

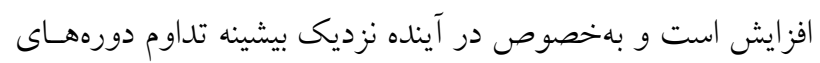
خشك هم در بازه يكساله افزايش زيـادى نشـان مسىهــــ امـا در

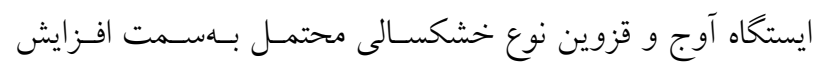

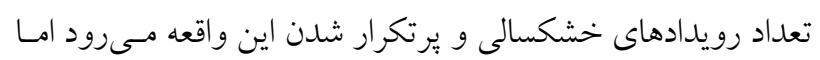

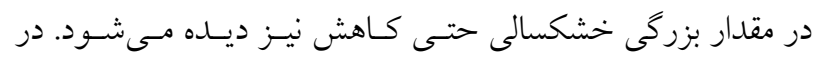

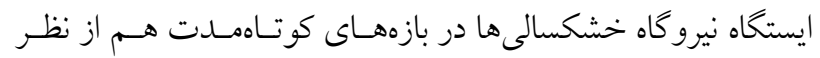

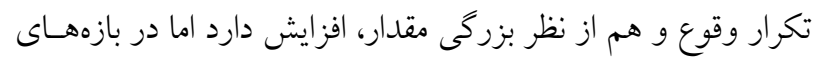

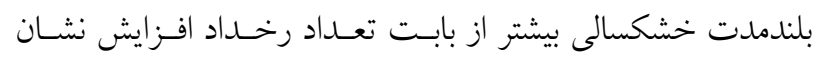

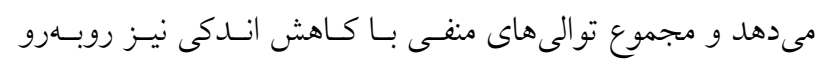

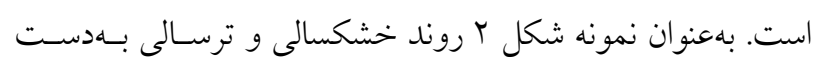
آمده از شاخص SPI را در آينده ايستخاه آوج نشان مى دهدي.

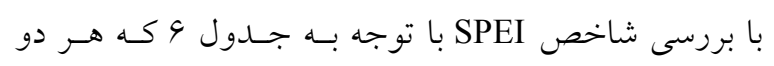

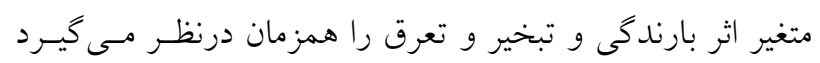

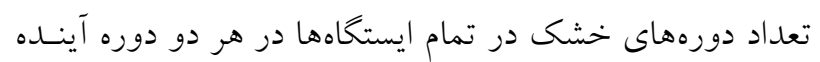

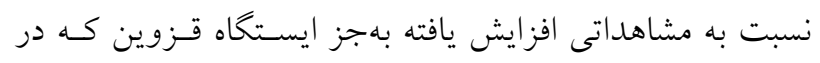

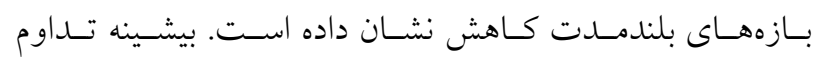
دورههاى خشك در همه ايستخاهها در بازه كوتاهمدت در آينـده

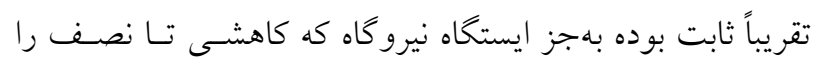

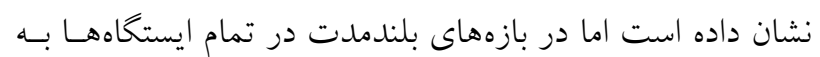
جز ايستخاه نيرو كاه بيشينه تداوم دوره خشكسـالى كـاهش يافتسهـ

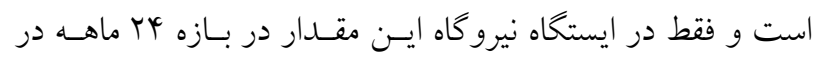

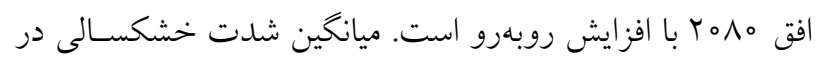

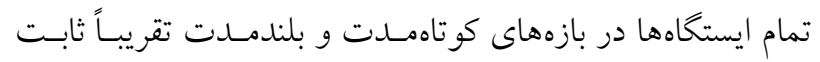
است. مجموع توالى هاى منفى در تمام ايستخاهها بـهـهـز ايستَّاه

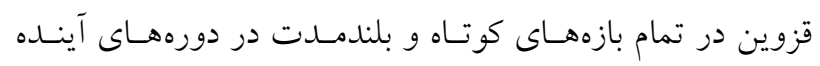

به مسائل ديخرى نيز ارتباط دارد كه تأثير بيّيجيـدهاى بــر آن مسى

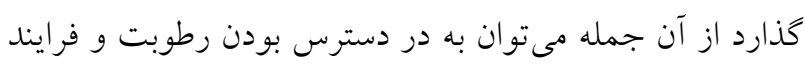

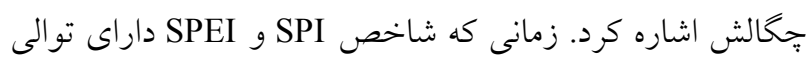

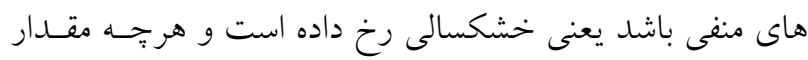

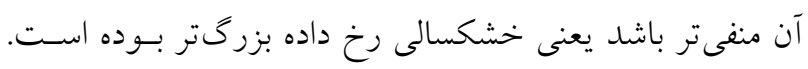

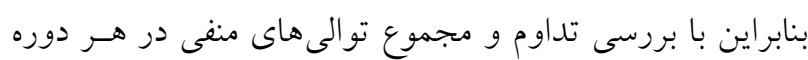
مى توان وضعيت خشكى رخ داده را بررسى كرد.

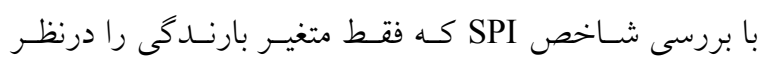

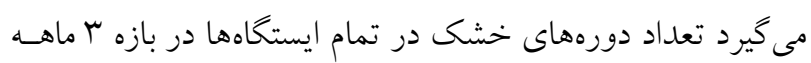

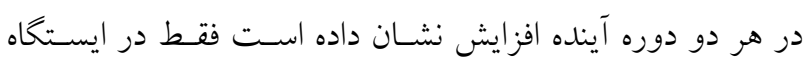

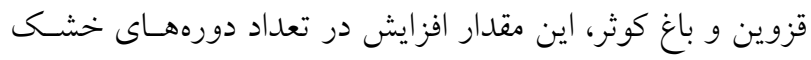

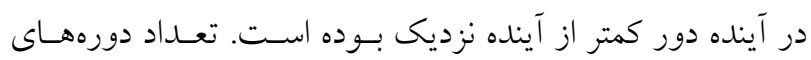

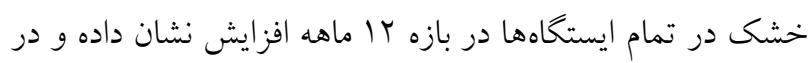

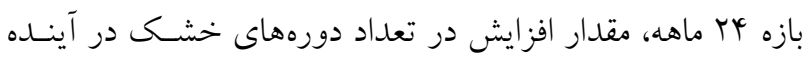

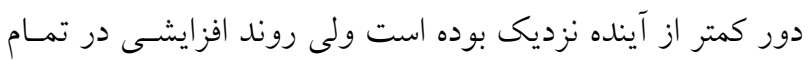

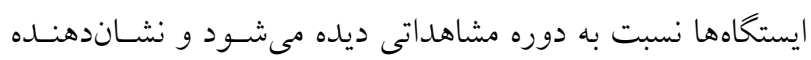
افزايش رويدادهاى خشكسالى در آينده اين دشت اسـت دئ. بيشـينه

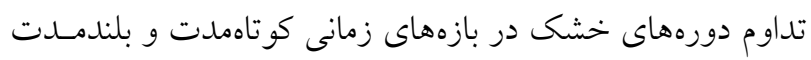

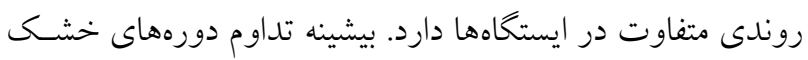

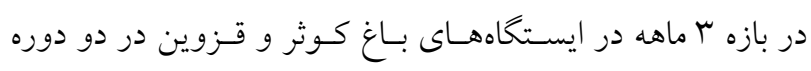

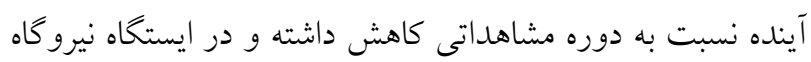

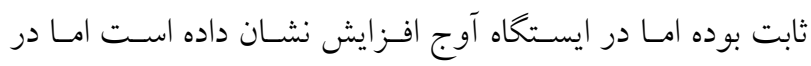

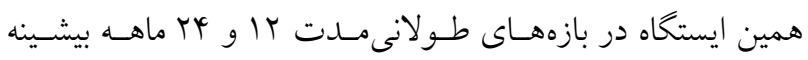
تداوم دورههاى خشك با كاهش مواجه شده است. بيشـينه تـداوم

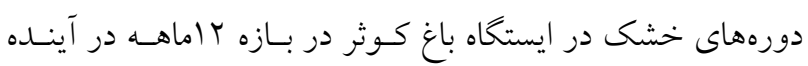

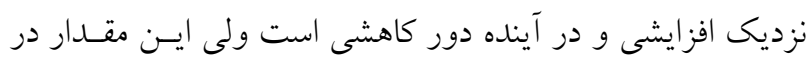

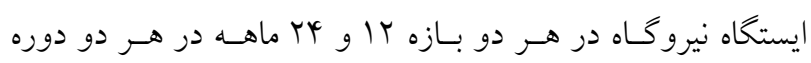

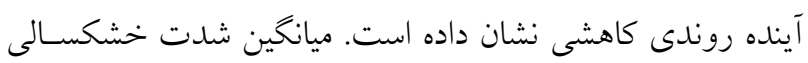

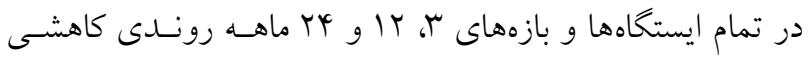

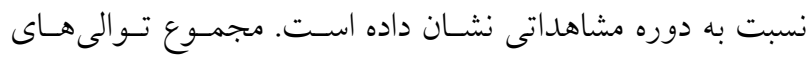

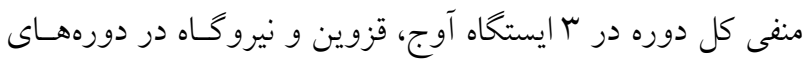

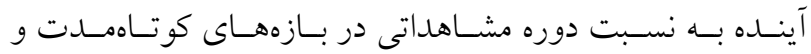




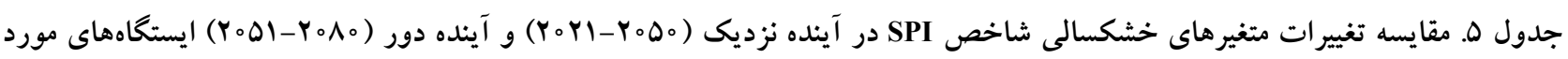
بررسى نسبت به دوره مشاهداتى

\begin{tabular}{|c|c|c|c|c|c|c|c|c|c|c|c|c|c|}
\hline \multicolumn{3}{|c|}{ مجموع توالىهاى منفى دوره } & \multicolumn{3}{|c|}{ خشكسالى ميانى } & \multicolumn{3}{|c|}{ بيشينه تداوم دوره خشك (ماه) } & \multicolumn{3}{|c|}{ تعداد دورههاى خشكى } & \multirow{2}{*}{ دوره زمانى } & \multirow{2}{*}{ ايستخاه } \\
\hline L ماهب & كاهـ & كاهمه & LAtry & باراهد & " آماهد & 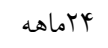 & Tاراهد & " آماهده & 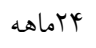 & 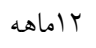 & " اماهده & & \\
\hline$-1 \mu \circ / 1$ & $-1 \mu y / \mu$ & $-1 \mu \pi / 4$ & $-0 / \wedge$ & $-0 / 9$ & $-0 / \wedge$ & 01 & r & 10 & 101 & lQT & $19 \mathrm{~V}$ & دوره مشاهداتى & \\
\hline \multirow[t]{2}{*}{$-1 Y N / 9$} & \multirow[t]{2}{*}{$-1 \mu \circ / 0$} & \multirow[t]{2}{*}{$-1 Y \varepsilon / r$} & \multirow{2}{*}{$-\circ / V$} & \multirow{2}{*}{$-\circ / V$} & \multirow{2}{*}{$-\circ / V$} & \multirow{2}{*}{ r } & \multirow{2}{*}{ rA } & \multirow{2}{*}{ ro } & \multirow{2}{*}{$M r$} & \multirow{2}{*}{ IVV } & \multirow{2}{*}{$1 \wedge t$} & سناريوى A2-mean & \multirow{4}{*}{ آوج } \\
\hline & & & & & & & & & & & & $(Y \circ \Delta \circ-Y \circ Y \backslash)$ & \\
\hline \multirow{2}{*}{$-\mid Y \Lambda / 4$} & \multirow{2}{*}{$-1 \mu \circ / V$} & \multirow{2}{*}{$-1 Y \varepsilon / 0$} & \multirow{2}{*}{$-\circ / V$} & \multirow{2}{*}{$-\circ / V$} & \multirow{2}{*}{$-\circ / V$} & \multirow{2}{*}{$\mu_{1}$} & \multirow{2}{*}{ TV } & \multirow{2}{*}{$r_{0}$} & \multirow{2}{*}{ IVA } & \multirow{2}{*}{ IVV } & \multirow{2}{*}{$1 \wedge \Delta$} & سناريوى A2-mean & \\
\hline & & & & & & & & & & & & $(Y \circ \Lambda \circ-Y \circ \Delta \mid)$ & \\
\hline$-9 V / 9$ & $-99 / 9$ & $-9 r$ & $-0 / \wedge$ & $-0 / \wedge$ & $-\circ / N$ & 90 & rt & 10 & ITr & IrT & ITS & دوره مشاهداتى & \\
\hline$-1 \pi 4 / 9$ & $-1 \mu \omega / q$ & $-1 T \Delta / 9$ & $-0 / 9$ & $-\circ / V$ & $-\circ / V$ & $4 \pi$ & $\Delta \Delta$ & 10 & 101 & $1 / k$ & IVT & A2-mean سناريوى & \\
\hline & & & & & & & & & & & & $(Y \circ \Delta \circ-Y \circ Y I)$ & 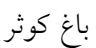 \\
\hline$-1 Y N / 0$ & $-|\mu| / 1$ & $-\mid K K / \Lambda$ & $-\circ / V$ & $-\circ / V$ & $-\circ V$ & Vo & ז & 11 & IVo & 14 & IVV & سناريوى A2-mean & \\
\hline$-11 / \lambda / \omega$ & $-111 / \lambda$ & $-11 T / \lambda$ & $-0 / \mathrm{V}$ & $-0 / v$ & $-0 / \mathrm{N}$ & vo & 11 & 11 & $10 \omega$ & $1 M$ & IV & $(Y \circ \Lambda \circ-Y \circ \Delta I)$ & \\
\hline$-1 T V / 0$ & -140 & $-1 k \mu / \mu$ & $-0 / 9$ & $-0 / \Lambda$ & $-0 / 9$ & 40 & $\mu y$ & ir & 100 & 199 & 191 & دوره مشاهداتى & \\
\hline$-1 \Gamma \Delta / \mu$ & $-1 \Gamma q / 9$ & $-1 T V / T$ & $-0 / V$ & $-\circ / V$ & $-\circ / V$ & VY & ry & 14 & IVA & INT & $1 \wedge F$ & سناريوى A2-mean & \\
\hline & & & & & & & & & & & & $(Y \circ \Delta \circ-Y \circ Y \backslash)$ & قزوين \\
\hline$-1 T V / 0$ & $-1 \Gamma q / 1$ & $-|\psi| / \mid$ & $-0 / \Lambda$ & $-\circ / V$ & $-\circ / \Lambda$ & r & TY & 9 & lQY & $|\wedge|$ & IVr & A2-mean سناريوى & \\
\hline & & & & & & & & & & & & $(Y \circ \Lambda \circ-Y \circ 01)$ & \\
\hline$-1+9 / 0$ & $-100 / T$ & $-109 / 1$ & $-1 / 4$ & $-1 / 9$ & $-0 / 9$ & 90 & rv & 11 & 1.4 & 99 & IrT & دوره مشاهداتى & \\
\hline$-1 \pi v / q$ & $-\mid Y \wedge / Y$ & $-1 r_{0} / 9$ & $-0 / 9$ & $-0 / 9$ & $-\circ / \Lambda$ & ra & TY & 11 & 149 & 101 & IOT & سناريوى A2-mean & \\
\hline & & & & & & & & & & & & $(Y \circ \Delta \circ-Y \circ Y \backslash)$ & نيرو كاه \\
\hline$-\| r V / V$ & $-1 \times q / 1$ & & -1 & -1 & $-0 / \Lambda$ & rq & TV & 11 & IFY & 149 & 149 & سناريوى A2-mean & \\
\hline & & & & & & & & & & & & $(Y \circ \Lambda \circ-Y \circ \Delta \mid)$ & \\
\hline
\end{tabular}
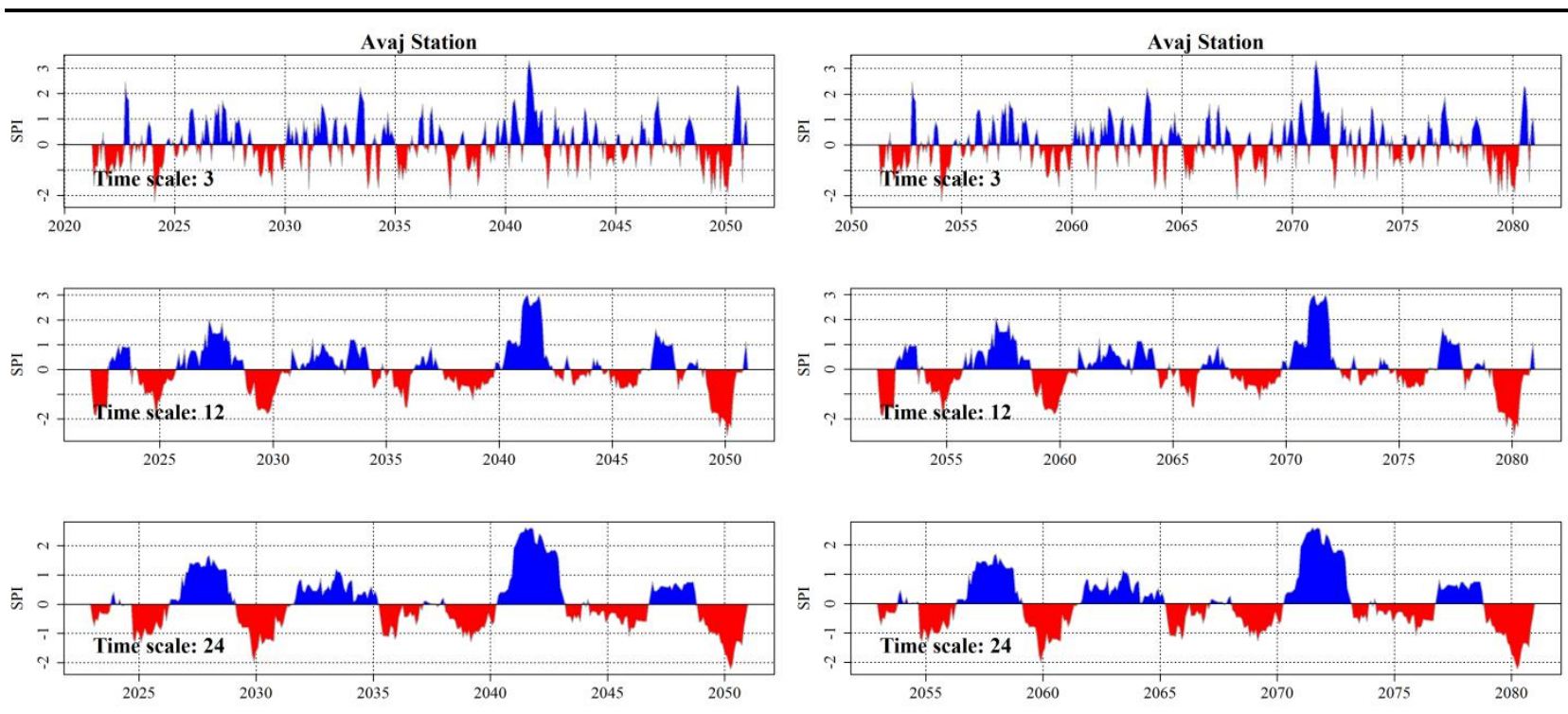

(الف)

(ب)

شكل r. روند خشكسالى و ترسالى شاخص SPI در ايستخاه آوج در: الف) آينده نزديك و ب) آينده دور 


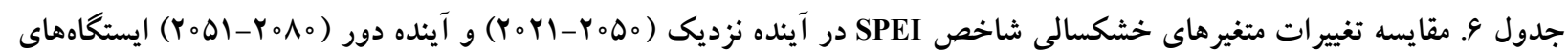
مورد بررسى نسبت به دوره مشاهداتى

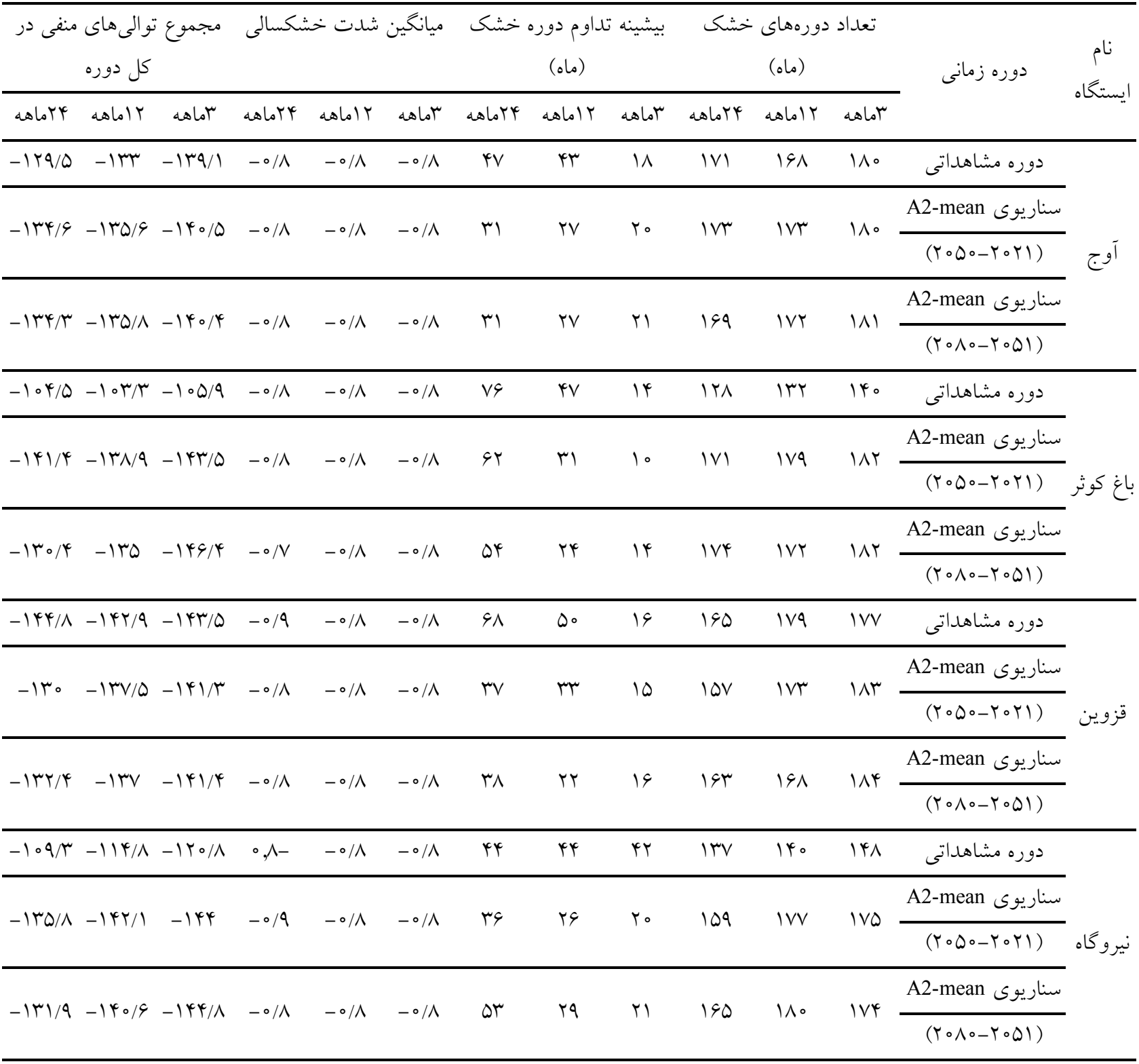

شد كه روند شاخص SPEI در دوره وسيعى از كشور افزايشى است بهنحوى كه روند دما و بارش در اكثر ايستخاهها بهترتيب افزايشسى و كاهشى اسـت. ايـن يزؤهشخران شاخص SPEI را بهعنوان ابزار مفيدى در زمينـه

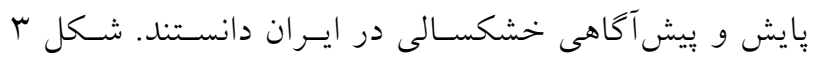
روند خشكسالى و ترسالى بهدست آمده از شـاخص SPEI را در ايستخاه باغ كوثر نشان مى دهد.
نسبت به مشاهداتى افـزايش نشـان داده و فقـط در ايسـتخاه قزوين اين مقدار كاهش نشان داده است. بدين معنى كه در ب

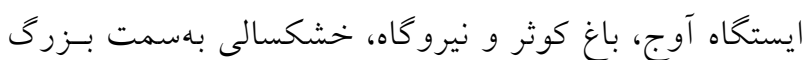
تر شدن و يرتكرارتر شـدن يــش مسىرود ولـى در ايسـتحاه قزوين از بابت شاخص SPEI خشكسـالى از بابست تعـداد و بزركى در دورههاى آينده نسبت به دوره مشـاهداتى كـاهش نشان مى دهد. در يُزوهش اقتدارنز اد و همكاران (1) خـزارش 

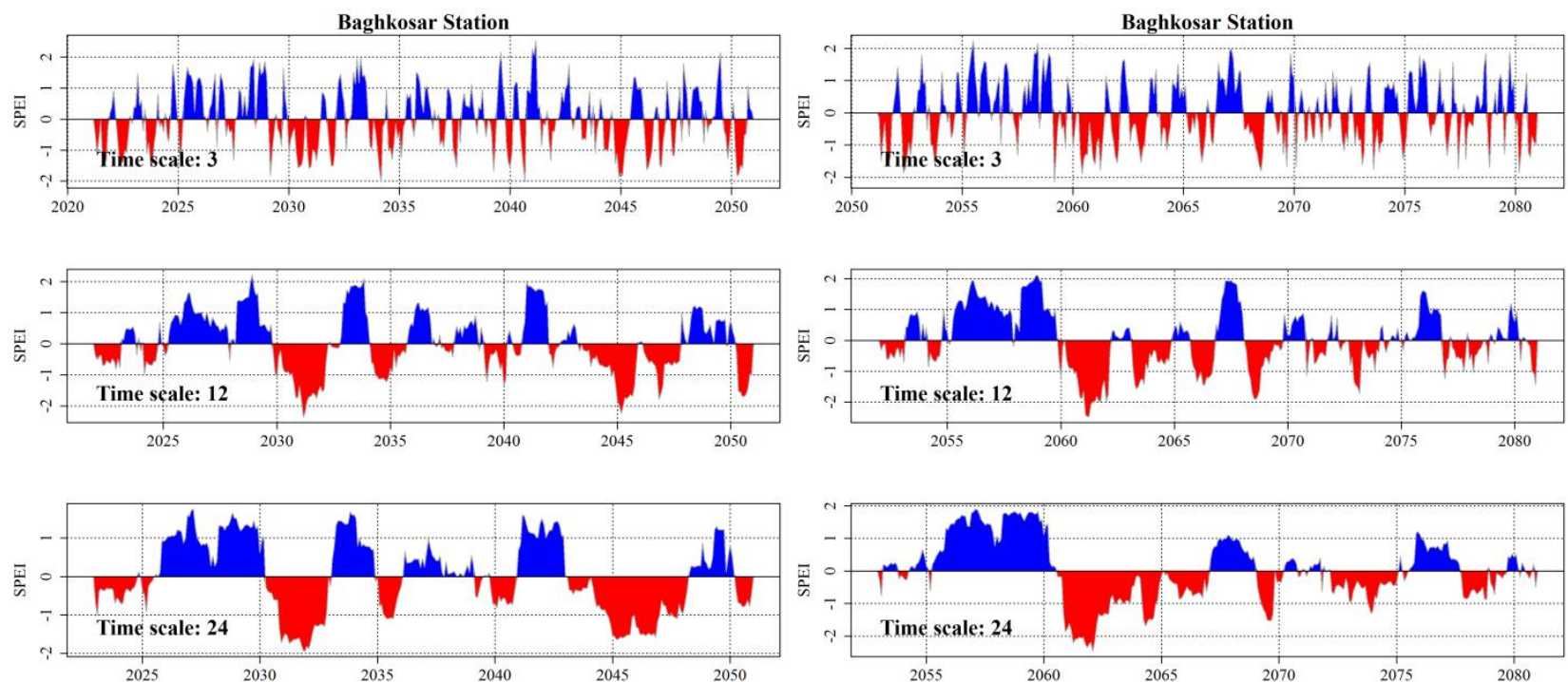

(الف)

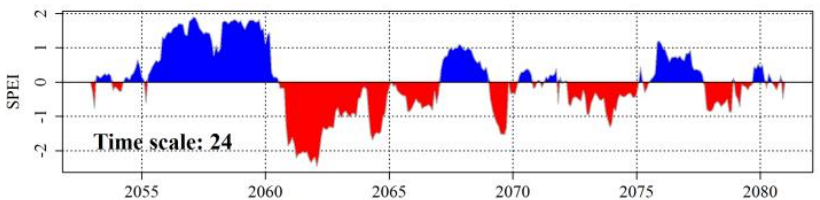

(ب)

شكل r. روند خشكسالى و ترسالى شاخص SPEI در ايستگاه باغ كوثر در: الف) آينده نزديك و ب) آينده دور

روبهرو است. در كل بين هر دو شـاخص خشكسـالى SPEI و SPI يك همبستخى مناسب وجود داشته و مىتوان بـا دقـت مناسـبى در

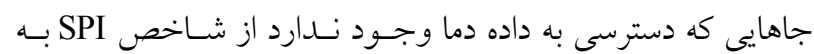
جاى SPEI استفاده كرد ولى مناسب است كه در شـرايطى كـه هـر دو سرى داده دما و بــارش وجــود دارنـــ از شـاخص SPEI بــراى بررسى خشكسالى استفاده كرد. در اين ميان بايد درنظر داشـت كـه تنوع در روش محاسبه تبخيروتعرق مىتواند بِاسخهـاى متفـاوتى را

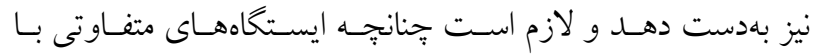
يكديخر مقايسه مىشوند بهروش محاسبه تبخيـروتعـرق نيـز دقـت شود جرا كه در محاسبه تبخيروتعرق در سادهترين حالت مسىتـوان فقط از داده دما استفاده كرد و در بييجيدهترين حالت در روش ينمن مانتيث، متغيرهاى باد، رطوبت، تـابش خورشـيدى و ... نيـز لحساظ مىشوند. شكل با نشاندهنده ارتباط بين دو شـاخص SPEI و SPI در اين بزوهش است. همان كونه كه ديده مىشود ايسن دو شـاخص

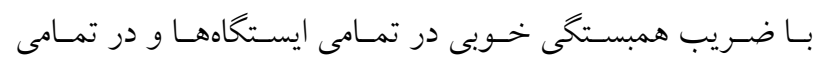

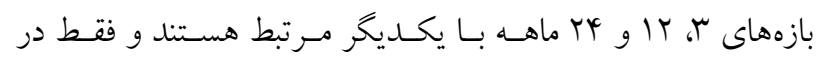

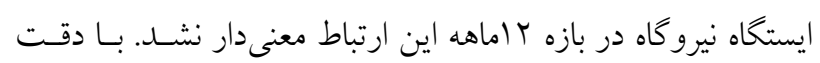
به شكل ب مشخص مىشود كه فقط در ترسالى هاى فرين (از ب بـه

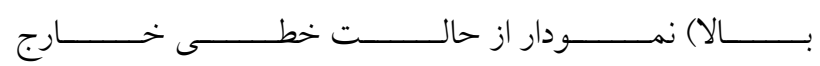

بين نتايجى كـه از شـاخص SPEI و SPI كرفتـه مسىشـود انـدكى تفاوت وجود دارد كه اين از ماهيت اين دو شـاخص برمسى آيـد. در شاخص SPI، خشكسالى فقط از بابت روند بارش بررسى مىشـود

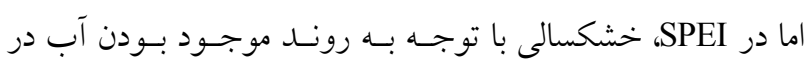
SPEI دسترس اقليمى بررسى مىشود بدين معنى كـه در شـاخص هم تغييرات بارندكى و هم تغييرات دمـايى همزمـان درنظـر كرفتـه مىشود و تغييرات دمايى از بابت تأثير بر ميزان تبخير كنندگى جـو و نياز تبخير و تعرق هم دخالت داده مىشود و مىتواند اتـر همزمـان تغييرات بارندكى و دما را بر رخداد خشكسالى نشان دهـــ. بـا ايسن تفسيرها اخر فقط شاخص SPEI درنظر گرفته شود ايستخاه قـزوين روندى متفــاوت از ب ايستخاه ديخـر را در آينــده نسـبت بـه دوره

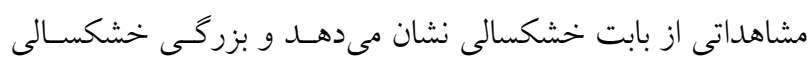
در آينده اين ايستخاه نسبت به دوره بايه كاهشى است و بــرعكس ب

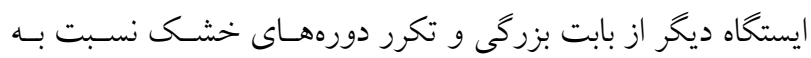
دوره هايه دجار افزايش خواهند بود. اما اخر فقط روند بارنـدگى بــر خشكسالى ملاكى عمل باشد فقط ايستخاه باغ كوثر از نظر بزرخى و تعداد دورههاى خشك در آينده نسبت به دوره بِيه با افزايش روبـهـ رو است و با ايستخاه ديخر بيشتر از نظر تعداد دورههاى خشكسالى با افزايش روبهرو هستند و بزرگى خشكسالى هاى محتمل با كاهش 


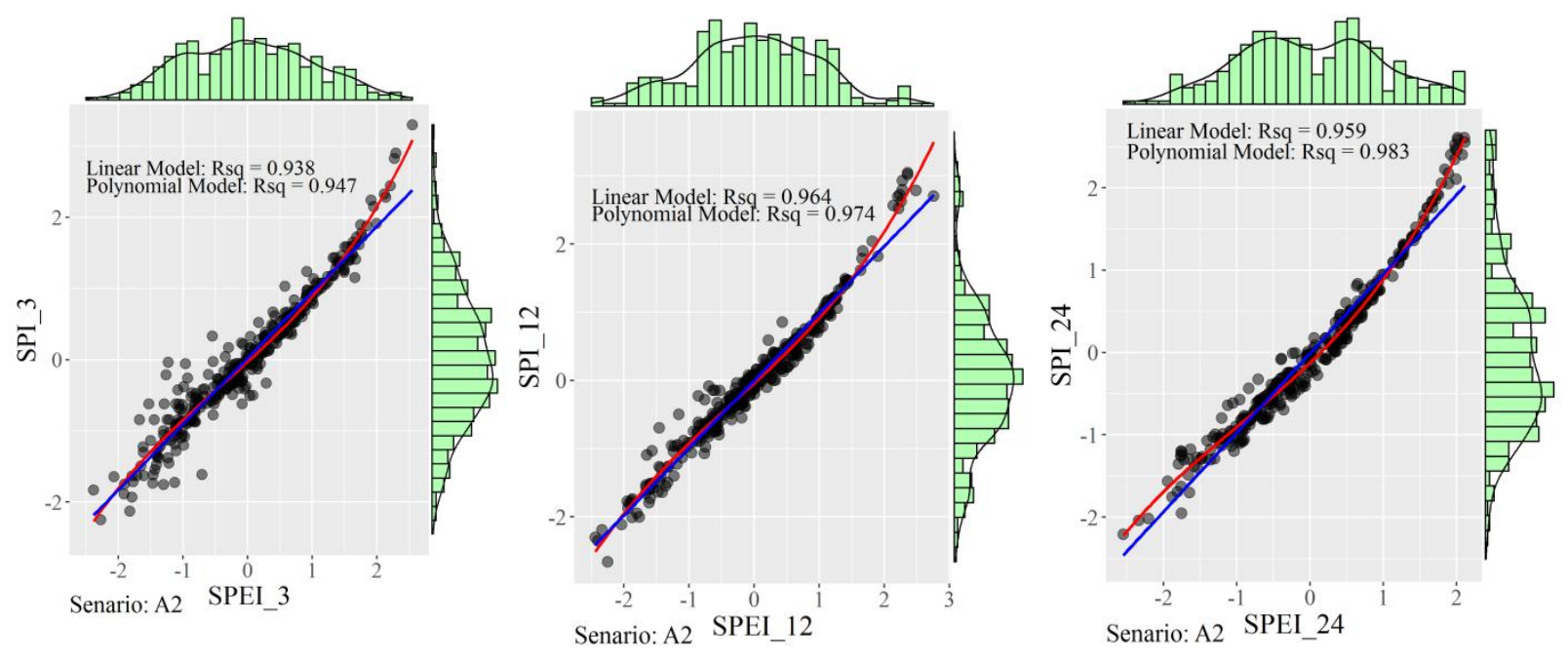

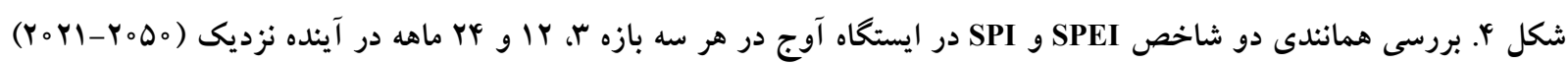

SPI در بازههاى "اماهــه كـهـ از منظـر كشـاورزى داراى اهميـتـ SPI

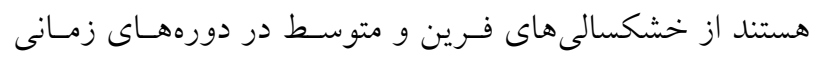
آينده نسبت به دوره مشاهداتى كاسته شده و خشكسالى هاى در طبقه شديد افز ايش نشـان داده اسـت و از طرفى ترسـالىهـاى لهـ

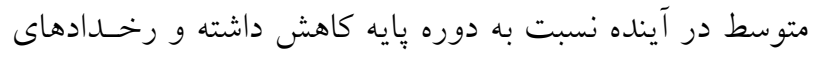

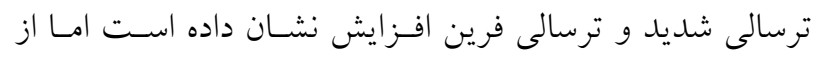

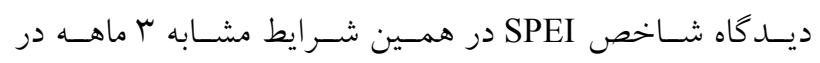

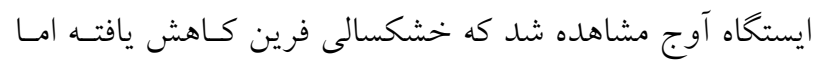

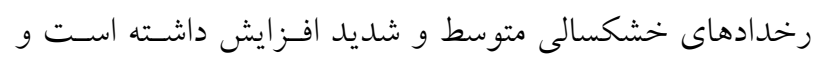

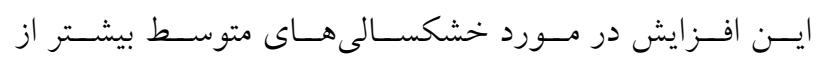

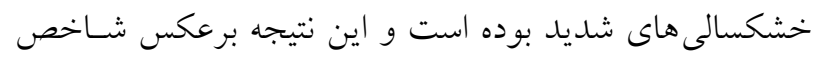

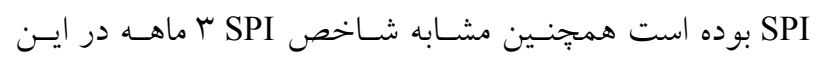

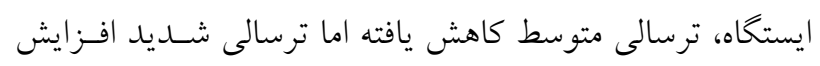

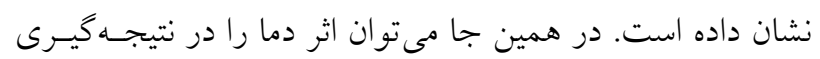

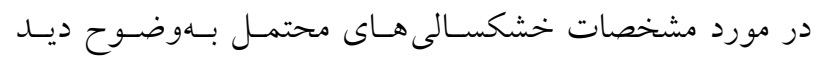

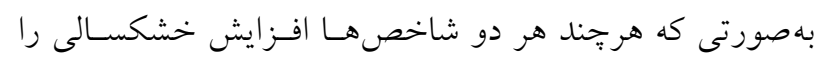

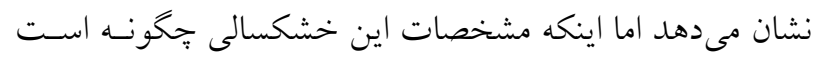

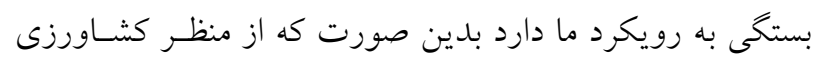
با افزايش دما و افزايش نياز تبخيروتعـرق، خشكسـالى متوسط بيشتر ديده مىشود درحالى كه بدون لحاظ كردن اثر دما و فقطط درنظر كرفتن اثر بارش، خشكسالى متوسط در دورههــاى آينــده
شده و شاخص SPI بهدليل درنظر نخرفتن اثر دما از خط نيمساز

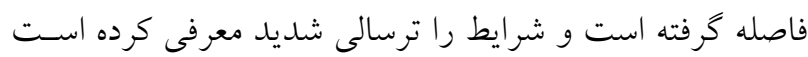

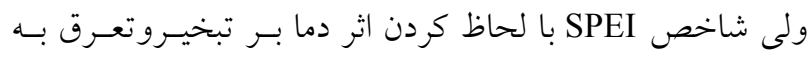

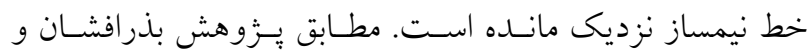

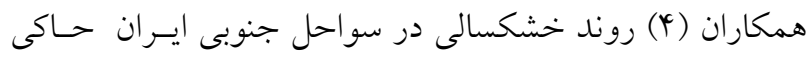

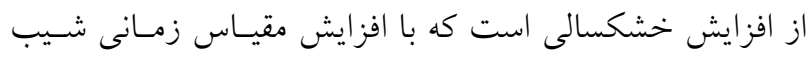

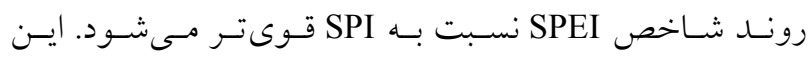
يزولهشكران نيز ييشنهاد كردند براى بررسى خشكسالى در اقليم

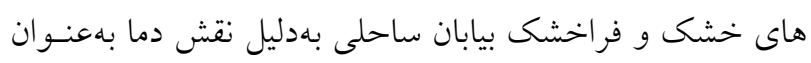

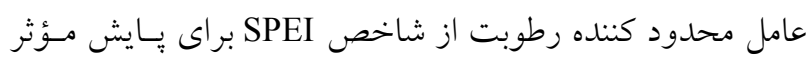

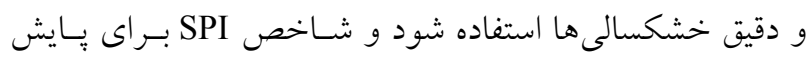
خشكسالى كافى نيست. مصطفىزاده و ذبيحى (19) در مقايســ

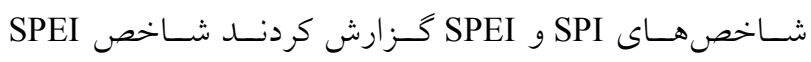
دورههاى طولانى تر خشكى را در اكثر ايستخاهها مشخص كرده

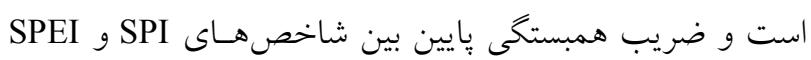

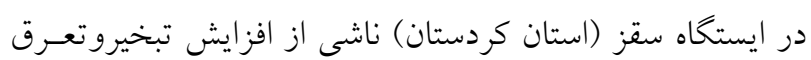
در فصل هاى بهار و تابستان بوده است و يـزّوهش ايشـان تـأثير دما در محاسبة SPEI را عامل تفاوت قابـل توجـه بسين مقـادير شاخص استاندارد مبتنى بـر بــارش و شـاخص تبخيـر و تعـرق مبتى بر دما، نشان داد.

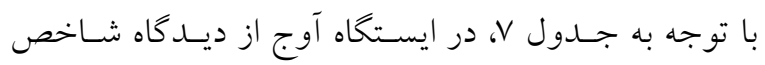


جدول V. طبقهبندى خشكسالى و ترسالى با استفاده از دو شاخص SPI و SPEI در دورههاى زمانى آينده نزديك و دور در ايستخاهها

\begin{tabular}{|c|c|c|c|c|c|c|c|c|c|c|c|c|c|c|c|c|c|c|c|c|c|c|}
\hline \multicolumn{9}{|c|}{ دوره زمانى •Y०Q1-Y } & \multicolumn{5}{|c|}{ دوره زمانى } & \multicolumn{7}{|c|}{ دوره مشاهداتى } & \multirow[b]{2}{*}{ خ شاخص ش شسالى } & \multirow[b]{2}{*}{ ستخاه } \\
\hline $\begin{array}{l}3 \\
3 \\
3 \\
3 \\
3 \\
3\end{array}$ & $\begin{array}{l}3 \\
3 \\
y \\
7 \\
3 \\
3 \\
3:\end{array}$ & $\begin{array}{l}3 \\
3 \\
3 \\
3 \\
3 \\
3 \\
3\end{array}$ & $\frac{3}{3}$ & $\begin{array}{l}3 \\
3 \\
3 \\
3 \\
3 \\
3 \\
3 \\
3\end{array}$ & $\begin{array}{l}1 \\
3 \\
3 \\
y \\
3 \\
3 \\
3 \\
3\end{array}$ & $\begin{array}{l}3 \\
3 \\
3 \\
y \\
3 \\
3 \\
3\end{array}$ & $\begin{array}{l}3 \\
3 \\
3 \\
3 \\
3 \\
3\end{array}$ & $\begin{array}{l}3 \\
3 \\
3 \\
3 \\
3 \\
3 \\
3:\end{array}$ & $\begin{array}{l}3 \\
3 \\
y \\
3 \\
3 \\
3 \\
-1\end{array}$ & $3^{3}$ & $\begin{array}{l}3 \\
\sqrt[3]{3} \\
3 \\
y \\
3 \\
3 \\
3\end{array}$ & $\begin{array}{l}3 \\
3 \\
3 \\
3 \\
3 \\
3 \\
3 \\
3 \\
3\end{array}$ & $\begin{array}{l}\cdot 3 \\
\sqrt[3]{3} \\
3 \\
y \\
3 \\
.3\end{array}$ & $\begin{array}{l}3 \\
3 \\
3 \\
3 \\
3\end{array}$ & $\begin{array}{c}3 \\
3 \\
3 \\
3 \\
3 \\
3 \\
3\end{array}$ & $\begin{array}{l}3 \\
3 \\
y \\
3 \\
3 \\
3\end{array}$ & 3 & $\begin{array}{l}3 \\
3 \\
3 \\
y \\
3 \\
3 \\
3 \\
3\end{array}$ & $\begin{array}{l}3 \\
3 \\
y \\
y \\
3 \\
3 \\
3 \\
3\end{array}$ & $\begin{array}{l}.3 \\
3 \\
3 \\
3 \\
3 \\
.3\end{array}$ & & \\
\hline$r / Y$ & $r / 9$ & $10 / 1$ & $V I / \Lambda$ & $\mathrm{V} / \mathrm{\circ}$ & $4 / 0$ & $\circ / 9$ & $r / T$ & $r / 4$ & $10 / 1$ & $V T / r$ & $v / r$ & $\varphi / T$ &.$/ 9$ & $1 / 4$ & $r / r$ & $\mid r / 4$ & $9 N / 0$ & $\Lambda / \uparrow$ & $4 / 。$ & $r / \circ$ & SPI3 & \\
\hline I/V & $9 / \mathrm{N}$ & $\Lambda / 9$ & $94 / 0$ & $1 r / 4$ & $r / q$ & $\circ / 1$ & I/N & $9 / 1$ & $9 / 0$ & $94 / 0$ & $1 r / V$ & $r / 9$ & $\circ / 1$ & $1 / V$ & $r / 9$ & $9 / 1$ & $99 / \mathrm{V}$ & $9 / 0$ & $Y / 0$ & $r / 9$ & SPEI3 & \\
\hline$r / 4$ & $r / r$ & $\Lambda / r$ & $\sqrt{T / 4}$ & $r / 9$ & $9 / 0$ & $r / 0$ & $r / 4$ & $1 / 1$ & $9 / r$ & $V r / 9$ & $4 / 9$ & $9 / 0$ & $Y / \circ$ & $1 / r$ & $r / r$ & $1 r / 1$ & $99 / 1$ & $\Lambda / \circ$ & $r / V$ & $r / 。$ & SPI12 & \\
\hline$r / r$ & $1 / 4$ & $1 Y / 9$ & $9 N / T$ & $9 / 9$ & $9 / r$ & $1 / 4$ & $r / r$ & $1 / 4$ & $11 / \mathrm{N}$ & $99 / 1$ & $4 / 9$ & $9 / r$ & $1 / 4$ & $r / 1$ & $r / 9$ & $10 / 1$ & $99 / 1$ & $9 / 1$ & $r / l$ & $r / r$ & SPEI12 & \\
\hline$r / 0$ & $r / 9$ & $9 / 0$ & $V 1 / 0$ & $11 / 0$ & $r / 1$ & $\circ / 9$ & $r / 0$ & $r / 9$ & $9 / 0$ & $V 1 / \Lambda$ & $11 \%$ & $1 / \Lambda$ & $0 / 9$ & $\%$ & $r / l$ & $1 \pi / \Lambda$ & $90 / 1$ & N/9 & $r / 9$ & $\varphi / 0$ & SPI24 & \\
\hline $1 / 1$ & $0 / 9$ & $V / I$ & $V 0 / 9$ & $\mathrm{~V} / \mathrm{V}$ & $0 / 9$ & $\circ / 9$ & $1 / \wedge$ & $0 / 9$ & $V / A^{4}$ & $V 0 / 0$ & $\Lambda / 9$ & $\Delta / \Gamma$ &.$/ 9$ & $0 / r$ & $\mathrm{~V} / \mathrm{V}$ & $1 / 9$ & $99 / \pi$ & $\Lambda / r$ & $9 / 0$ & $r / D$ & SPEI24 & \\
\hline $1 / 1$ & $9 / 1$ & $10 / 9$ & $V 0 / 4$ & $9 / 4$ & $\varphi / r$ & $1 / 1$ & $1 / 1$ & $r / 0$ & $11 / 0$ & $99 / 1$ & $\mathrm{~V} / 0$ & $r / l$ & $r / l$ & $1 / 0$ & $r / \mathcal{T}$ & $10 / 4$ & $V Y / 0$ & $9 / r$ & $r / V$ & $r / 9$ & SPI3 & \\
\hline $0 / 9$ & $\mathrm{~V} / \mathrm{o}$ & $10 / 9$ & $q 4 / \Lambda$ & $11 / 0$ & $\Delta / r$ & $\circ / r$ & $1 / 4$ & $r / V$ & $11 / \mathrm{N}$ & $94 / \pi$ & $11 / r$ & $9 / 1$ & $0 / 9$ & $1 / 0$ & $9 / 0$ & $9 / r$ & $90 / V$ & $I T / V$ & $r / 4$ & $1 / 0$ & SPEI3 & \\
\hline $4 / 0$ & $r / v$ & $V / T$ & $V 1 / 9$ & $9 / 0$ & $\Delta / K^{\mathcal{C}}$ & $Y / 。$ & $1 / 1$ & $9 / 0$ & & $V Y / Y$ & $r / c$ & $\Delta / 4$ & $r / 4$ & $\circ / \Lambda$ & $4 / 9$ & $9 / \mathrm{V}$ & $99 / 1$ & $V / r$ & $V / r$ & $1 / r$ & SPI12 & باع \\
\hline .19 & $V / r$ & N/9 & $9 N / 0$ & $1 / 9$ & $Q / \Gamma$ & $1 / 4$ & $0 / 9$ & $V / r$ & $9 / r$ & $9 V / 9$ & $9 / 9$ & $9 / 9$ & $1 / 4$ & $\%$ & $\Lambda / 1$ & $11 / 9$ & $G Y / T$ & $I T / V$ & $\Delta / 4$ & $\% / 0$ & SPEI12 & كوثر \\
\hline $1 / r$ & $11 / r$ & $r / V$ & $\mathrm{~V} / \mathrm{A}$ & $9 / 1$ & $r / \mathcal{F}$ & $0 / 9$ & $\%$ & $1 / 1$ & $1 V / 0$ & $94 / 4$ & $V / I$ & $Q / \circ$ & $r / r$ & $\circ / \Lambda$ & $1 / 0$ & $\Delta / r$ & $99 / 4$ & $10 / 1$ & $r / r$ & $\circ / 0$ & SPI24 & \\
\hline$\%$ & $9 / 1$ & $9 / 0$ & $V 0 / 9$ & $9 / \pi$ & $r / r$ & $r / 9$ & $\%$ & $r / r$ & $\mid M / 1$ & $\Delta 9 / 9$ & $9 / 0$ & & & $\%$ & $4 / 9$ & $\mid V / 4$ & $G T / r$ & $11 / V$ & $r / 9$ & $\%$ & SPEI24 & \\
\hline $1 / V$ & $4 / 0$ & $9 / 0$ & $9 \mathrm{~V} / \mathrm{r}$ & $10 / 9$ & $r / q$ & $r / T$ & $T / Y$ & $r / 1$ & $10 / 1$ & $V 1 / r$ & $\Lambda / 1$ & $r / l$ & $T / T$ & $r / 0$ & $r / T$ & $9 / r$ & $V_{0} / l$ & $1 / 4$ & $\psi / V$ & $r / 1$ & SPI & \\
\hline $1 / V$ & $\Delta / r$ & 11,0 & $94 \%$ & $\mid r / r$ & $Y / V$ & $0 / 9$ & & $\psi / V$ & $I r / r$ & $99 / \pi$ & $9 / 5$ & $r / V$ & $1 / 1$ & $T / r$ & $r / q$ & $1 / 9$ & $9 V / 9$ & $1 T / 0$ & $r / 4$ & $1 / V$ & SPEI3 & \\
\hline$\varphi / 0$ & $r / q$ & $4 / 9$ & $V \psi / \Lambda$ & $V / r$ & $\Delta / V$ & $0 / 9$ & $r / 4$ & $r / q$ & $9 / r$ & $V Q / 1$ & $\Lambda / \circ$ & $r / 。$ & $\circ / r$ & $\%$ & $r / r$ & $1 T / 9$ & $9 N / Y$ & $Q / \mathcal{F}$ & $r / r$ & $\Delta / r$ & SPI12 & \\
\hline$r / 9$ & $r / \mu^{k}$ & $9 / 9$ & $9 N / 0$ & $1 T / 0$ & $\Delta / V$ & $0 / 9$ & $r / 9$ & $r / r$ & $V / 4$ & $99 / 9$ & $10 / 9$ & $Q / V$ & $0 / 9$ & $\%$ & $V / V$ & $10 / 9$ & $99 / 1$ & $\Lambda / \circ$ & $\Delta / V$ & $1 / 1$ & SPEI12 & \\
\hline$r / 9$ & $1 / 0$ & $V / I$ & $9 N / 1$ & $1 \pi / 9$ & $r / 0$ & $0 / 9$ & $9 / 1$ & & & & $\mid r / T$ & & & $0 / r$ & $r / q$ & & & $\Lambda / r$ & $r / V$ & $r / 9$ & & \\
\hline$r / 。$ & $r / 4$ & $V / V$ & $90 / 9$ & $10 / 4$ & $\Delta / \Gamma$ & $0 / r$ & $Q / 。$ & $r / l$ & $r / 9$ & $V 0 / 9$ & $1 T / 0$ & $r / r$ & $r / 4$ & $\%$ & $r / 9$ & $19 / 9$ & $\Delta N / \Lambda$ & $10 / 1$ & $0 / 9$ & $\%$ & SPEI24 & \\
\hline I/V & $r / q$ & $11 / r$ & $\mathrm{~V} / \mathrm{A}$ & $9 / 1$ & $T / T$ & $r / 1$ & $1 / 4$ & $r / 0$ & $10 / 1$ & $V r / V$ & $\varphi / \theta$ & $r / 4$ & $r / D$ & $1 / 0$ & $\psi / 。$ & $10 / V$ & $9 N / D$ & $10 / V$ & $r / r$ & $T / V$ & SPI3 & \\
\hline$r / 0$ & $\Delta / \Gamma$ & $10 / 1$ & $90 / 9$ & $11 / r$ & $0 / \circ$ & $\circ / \wedge$ & $r / 0$ & $\Delta / r$ & $9 / 0$ & $9 \mathrm{~V} / \mathrm{r}$ & $9 / 1$ & $\Delta / r$ & $\circ / \Lambda$ & $\circ / V$ & $9 / 4$ & $10 / 4$ & $90 / 4$ & $11 / V$ & $\psi / V$ & $\circ / V$ & SPEI3 & \\
\hline $0 / r$ & $1 / V$ & $19 / 9$ & $90 / 9$ & $r / v$ & $r / r$ & $\Lambda / r$ & $\circ / 0$ & $1 / V$ & $14 / 9$ & $99 / r$ & $\psi / \mu$ & $\psi / \mu$ & $\Delta / V$ & $\%$ & $\%$ & $1 \pi / 1$ & $99 / 1$ & $\psi / \Lambda$ & $r / \Lambda$ & $1 \pi / 1$ & SPI12 & \\
\hline $1 / V$ & $r / \mu^{c}$ & $1 r / \Delta$ & $94 / \Lambda$ & $1 / 9$ & $V / r$ & $0 / 9$ & $0 / 9$ & $4 / 0$ & $19 / 0$ & $G T / T$ & $\Lambda / 9$ & $V / x$ & $\circ / 9$ & $r / \Lambda$ & $1 / V$ & $9 / 0$ & $99 / 4$ & $\Lambda / r$ & $11 / 1$ & $\circ \%$ & SPEI12 & \\
\hline$\%$ & $r / r$ & $\mid r / r$ & $V I / r$ & $r / r$ & $r / 。$ & $V / I$ & $\circ / r$ & $r / V$ & $1 \pi / 9$ & $9 N / \%$ & $V / V$ & $r / 。$ & $\varphi / V$ & $\%$ & $\%$ & $9 / 0$ & $V Q / \Lambda$ & $\varphi / 。$ & $r / D$ & $\Lambda / V$ & SPI24 & \\
\hline$r / 0$ & $r / 。$ & $V / \mathrm{l}$ & $V 0 / 0$ & $9 / r$ & $Q / \Gamma$ & $r / 4$ & $1 / 0$ & $\psi / V$ & $\Lambda / \circ$ & $V 0 / 0$ & $\Lambda / r$ & $\varphi / \Delta$ & $r / 0$ & $1 / 4$ & $V / r$ & $\varphi / 0$ & $V_{0} / 4$ & $V / 9$ & $\Lambda / V$ & $\circ / 4$ & SPEI24 & \\
\hline
\end{tabular}

كاهش نشان مى دهد همجنين خشكسالى هاى متوسط نيز كم شده و به تعداد خشكسالى هاى شديد اضافه مىشود. در بازه با ماهـــ كه از منظر هيدرولوزيك داراى اهميت است شاخص SPI نشـان از افزايش خشكسالى هاى متوسط و همجنين ترسالى هاى شديد و فرين دارد درحالى كه شاخص SPEI فقط از افزايش خشكسـالى
كاهش داشته و فقط خشكسالى هاى شديد افززايش انـدى نشـان داده است. شاخص SPI در بازههاى زمـانى Tr آماهـه در ايسـتخاه

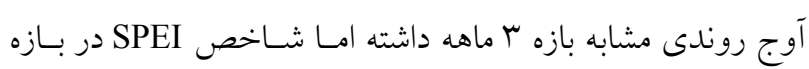

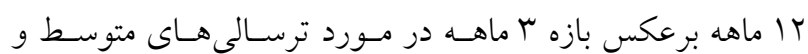
فرين در افق زمانى •Nم افزايش و در مورد ترسالىهاى شـديد، 
نشان داده مسىشـود و همجنـسين رخهـدادهاى خشكسـالى از بـازه

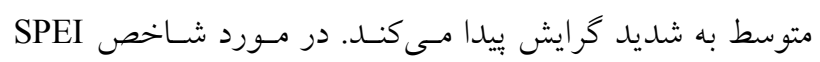

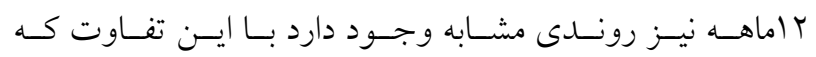

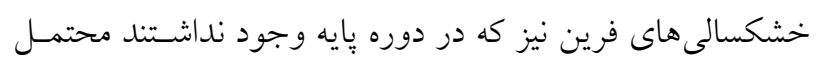

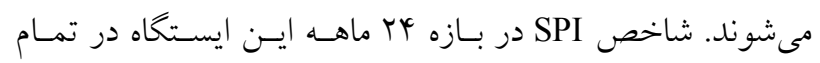

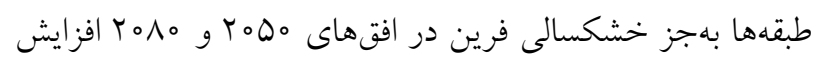

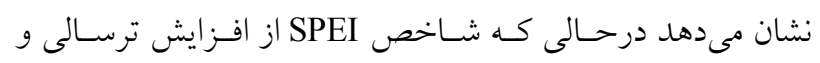
خشكسالى متوسط و خشكسالى و ترسالى فرين خبر مىدهد.

\section{نتيجه كيرى}

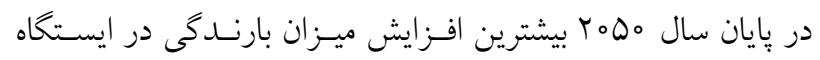

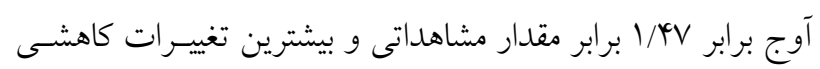

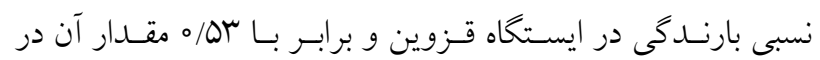
دوران مشاهداتى نشـان داده شـد. در همسين دوره زمـانى بيشـترين

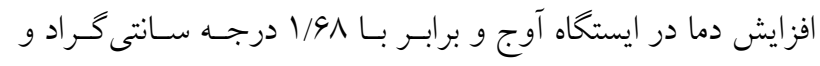

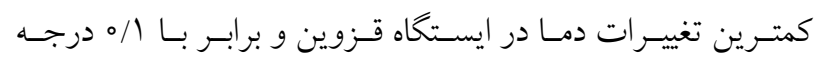

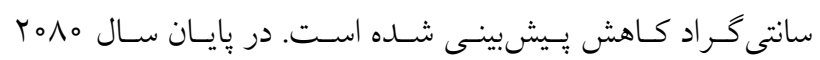

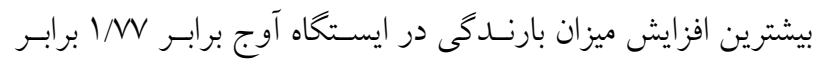

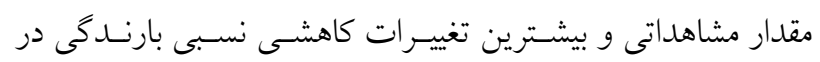

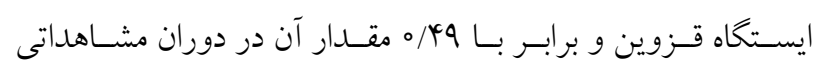

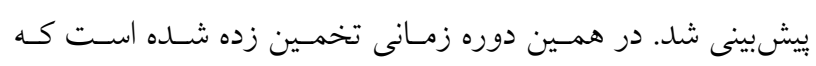

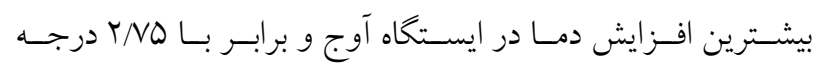

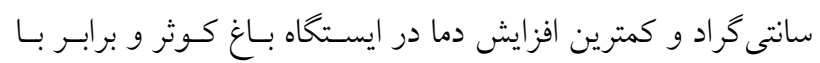

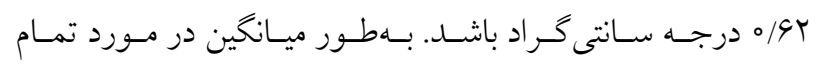

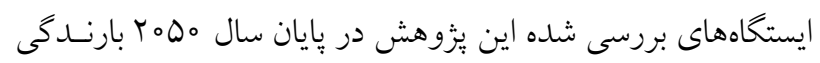

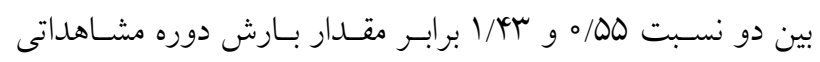

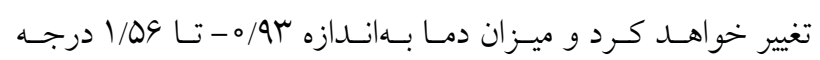

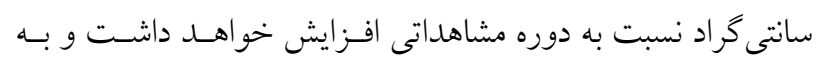

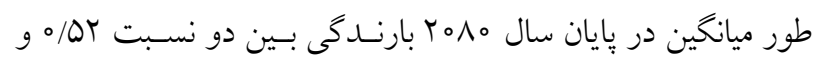

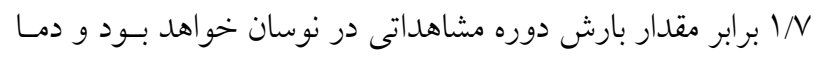

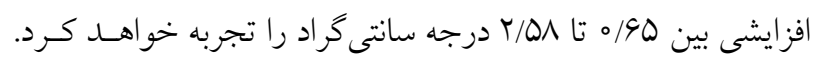

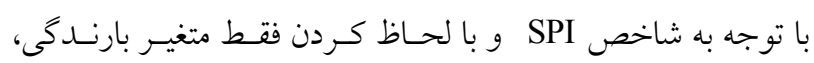

متوسط و ترسالى فرين گزارش مى دهد. بايــــ توجـه داشـت ايـن

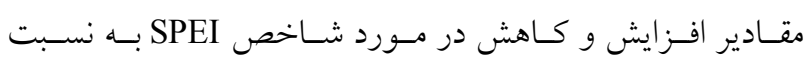
شاخص SPI روند ملايمترى دارد. در مـورد ايستخاه بــاغ كـوثر،

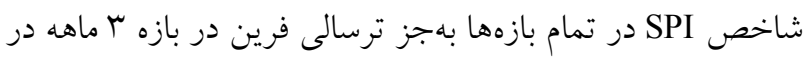

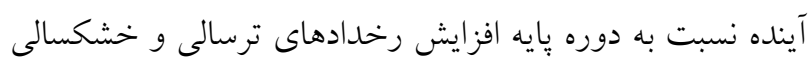

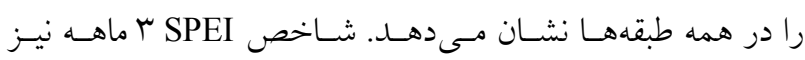

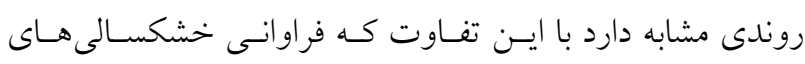

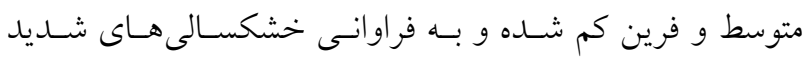

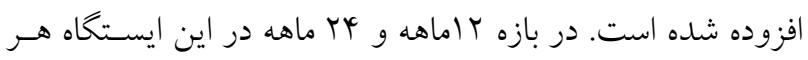

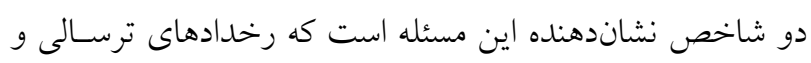

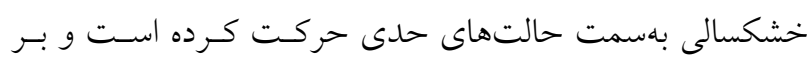
درصد فراوانى خشكسالىها و ترسالىهاى فرين و شـــيد افـزودها

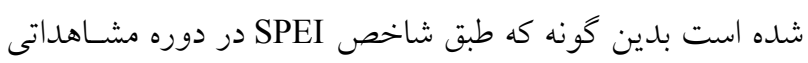

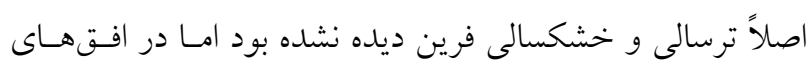

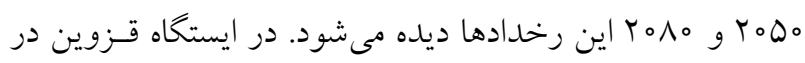

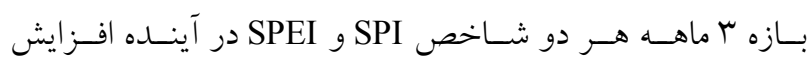

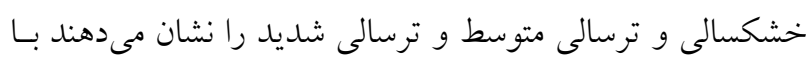

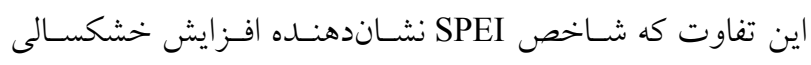

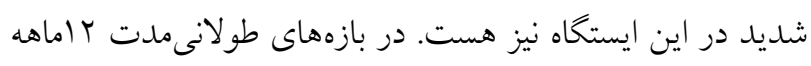

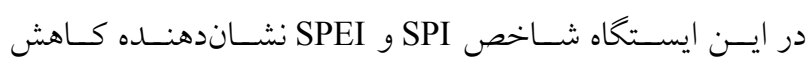

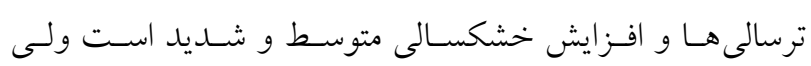

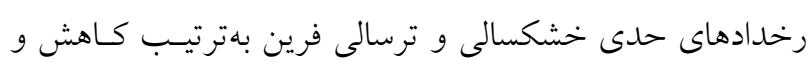

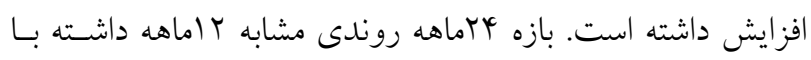
اين تفاوت كه در شاخص SPEI درصد فراوانى خشكسالى فرين

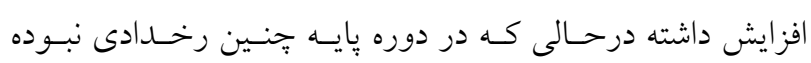

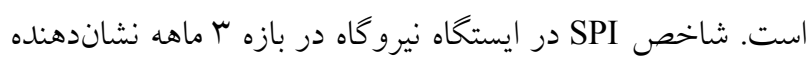

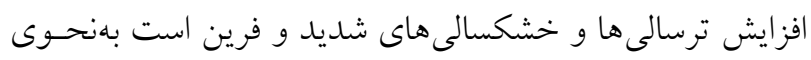

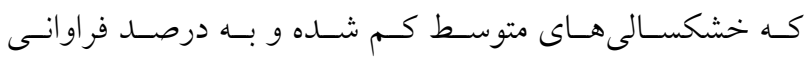
خشكسالى هاى شديدتر افزوده شده است. شاخص SPEI ب ماهـ نيز در مورد خشكسالى ها روندى مشابه دارد. در بازه با اماهه نيـز

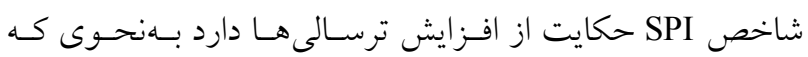

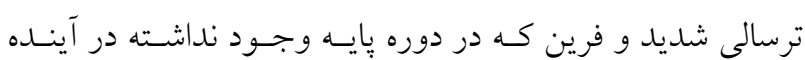


كاهشى تا نصف را نشان داده است. در بازههاى بلندمــت در تمـام

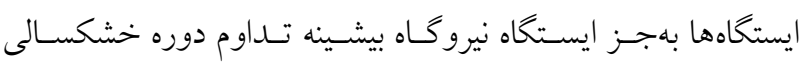

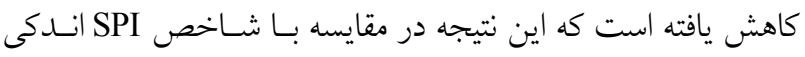

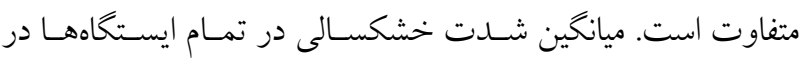

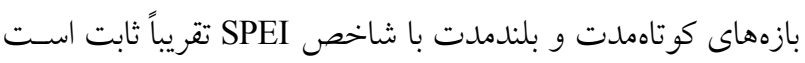
درحسالى كـه در شـاخص SPI رونسـدى كاهشـى دارد. مجمــوع توالىهاى منفى در شاخص SPEI در تمام ايستكاهها بهجز ايستخاه

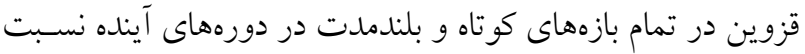
به مشاهداتى افزايش نشان داده و فقط در ايستخاه قزوين اين مقــار كاهش نشان داده است كه اين نتيجه با شاخص SPI متفاوت اسـت

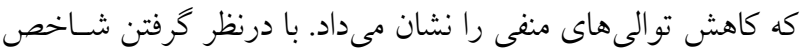
SPEI (محور جنوبغربى به شمالشرقى)، كاهش بزرخى خشكسـالى را

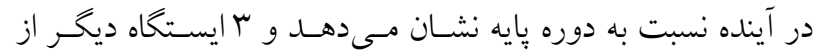

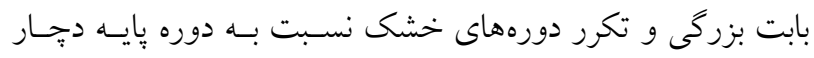

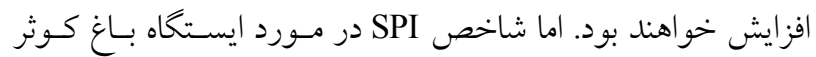

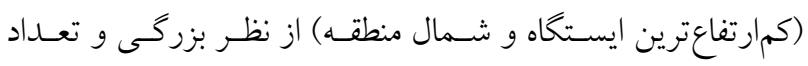
دورههاى خشك در آينده نسبت به دوره بايه افز ايش نشـان داده و

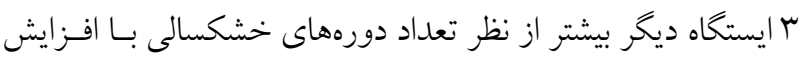

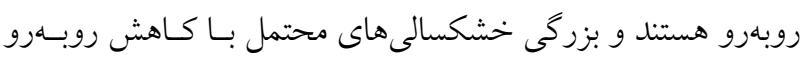

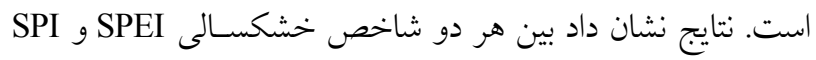

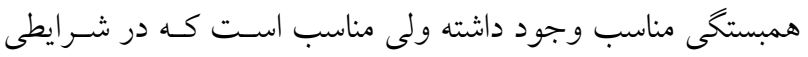

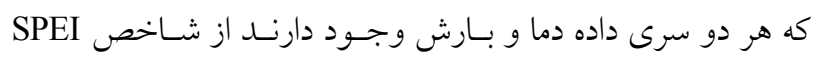
براى بررسى خشكسالى استفاده كـرد تـا ديـــ بهتــى از جزئيـات

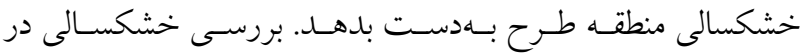

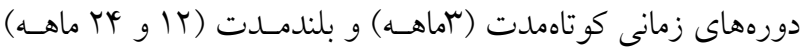

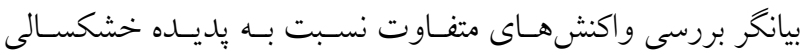
است. دورههاى كو تامملت ( ب ماهه) كه بيشتر بـر رطوبـت خـاك و مسئله كشاورزى تأثير خود را نشان مى دهل، فراوانى وقوع بيشسترى

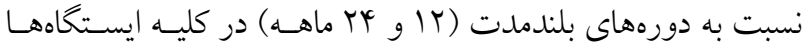

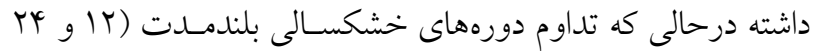
ماهه) نسبت به كوتاهمدت (ماهه) بيشتر است و ايسن نشـانكر ايسن

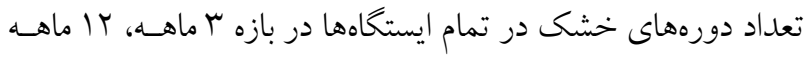

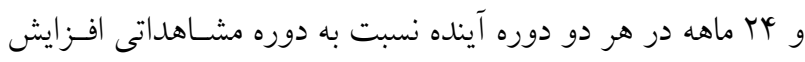

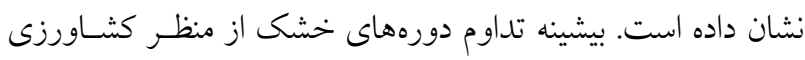

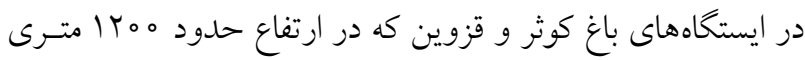

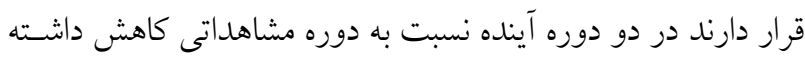

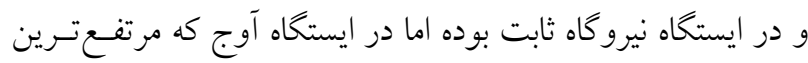

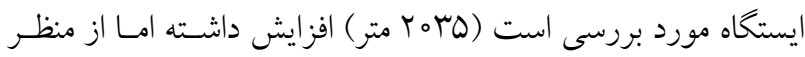

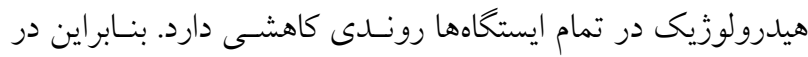

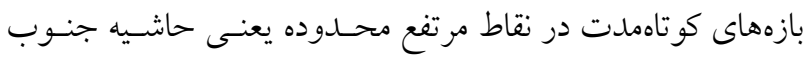
غربى منطقه با افزايش تداوم دورههاى خشك مواجه خواهيم بـود و

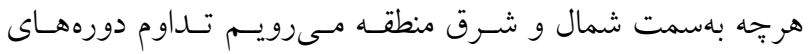
خشك كاهش نيز مسيابــ. ميـانكين شـدات خشكسـالى در تمـام

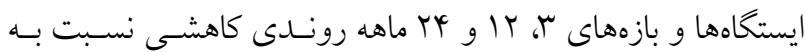

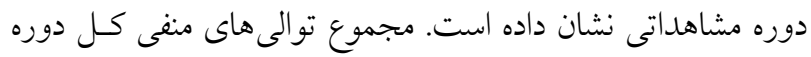

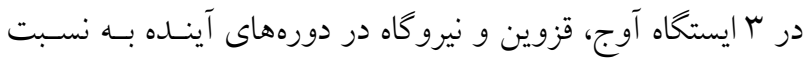

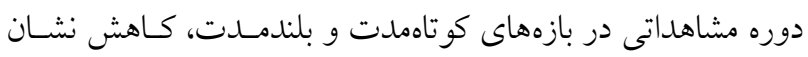

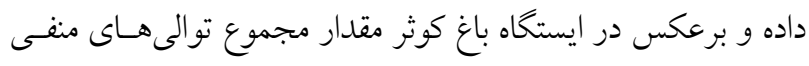

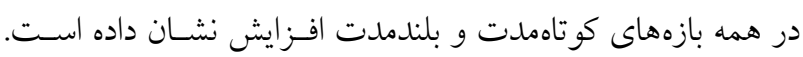
بنابراين در ايستگاه باغ كوثر (شمال منطقه و كمارتفاعترين ايستخاه مورد بررسى) تعداد رويدادهاى خشكسـالى و بزركى آن در آينـاه

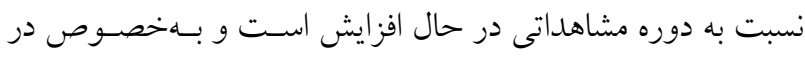

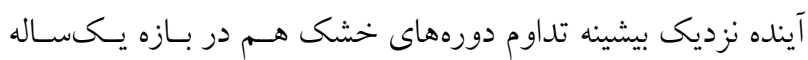

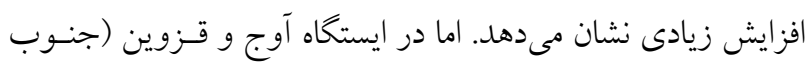

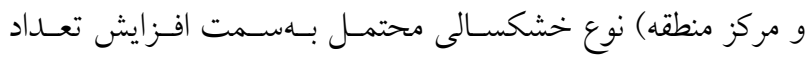
رويدادهاى خشكسالى و يرتكرار شدن اين رخداد مسرود ولى در مقدار بزركى خشكسالى حتى كاهش نيز ديده مىشود. با توجسه بـهـ شاخص SPEI و با لحاظ كردن هر دو متغيـر اتـــــارنـــى و دمـا،

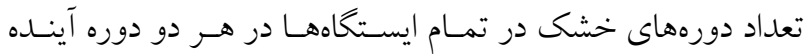
نسبت بـه مشـاهداتى مشـابه شـاخص SPI فـز ايش يافتـه بـهــز ايستاه قزوين (مركز منطقه) كه در بازههاى بلندمدت كاهش نشـان داده است. بيشينه تداوم دورههاى خشك در همه ايستخاهها در بـازه

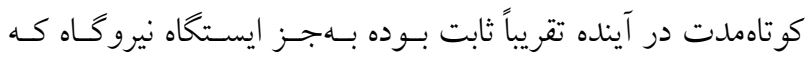


خشكسالى شديد و ترسالى متوسط اشـاره دارد و هرجهـه بـهسمت بازههاى بلندمدت مىرود ترسالى و خشكسالى بـهسمت شـديد و فرين شدن بيش مىرود. در ايستخاه قزوين (مركز منطقه) از ديـدكاه شاخص SPI در بازههاى كوتاهمدت خشكسالى متوسـط و ترسـالى شديد افزايش مىيابد و هر جّه بهسمت بازههـاى بلندمــات مسىرود ترسالى هاى فرين نيز افـز ايش زيــادى نشـان مـىدهنـــــ از ديـــاه شاخص SPEI در بازههاى كوتاهمدت بهسمت افزايش خشكسـالى

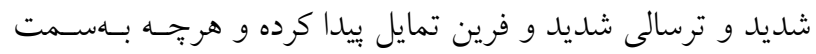
بازهاى بلندمدت مىرود خشكسالى هاى متوسط افـزايش يافتسه و ترسالىهاى فرين نمايان مىشـوند. در ايسـتخاه نيروگـاه، از ديـدكاه شاخص SPI خشكسالى و ترسالى متوسط در بازههاى كوتـاهمــت افزايش يافته و هر جهه بهسمت بازههاى بلندمدت مىرود بـه درصــ فراوانى خشكسالى هاى شـديد و متوسـط اضـافه شـده و همجنـــن ترسالىهاى فرين نيز محتمل مىشوند امـا از منظـر شـاخص SPEI خشكسالى هاى شديد و متوسط در بازههـاى كوتـاهمـــت افـزايش

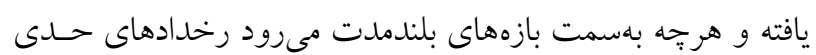
خشكسالى و ترسالى فرين نمايان مىشوند. آنجهه كه واقعاً در آينـده

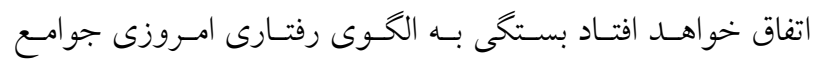
درخصوص توليد گازهاى گلخانهاى دارد.

$$
\begin{aligned}
& \text { مسئله است كه اثر منفى كمبود بارش در ايستخاههاى مـورد بررسى } \\
& \text { بر آبهاى زيرزمينى، جريان رودخانهها و ذخاير منـابع آبسى بيشـتر }
\end{aligned}
$$

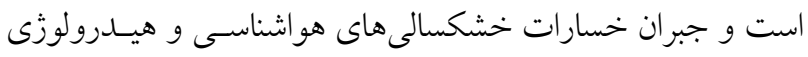

$$
\begin{aligned}
& \text { در اين ايستخاهها كه به كمبود بارش در دورههاى بلندمــت وابستهـه } \\
& \text { است، زمان طولانىتـرى مسى طلبـد. در ايسـتخاه آوج (مرتفـعتـرين } \\
& \text { ايسـتخاه) در جنــوب غربسى منطقــه از ديــدكاه شــاخص SPI در } \\
& \text { بازههاى كوتاهمدت افزايش خشكسالى و ترسالى شــيد و ترسـالى } \\
& \text { فرين مشاهده مىشود و هرجهه بهسمت بازههاى طولانىمدت مسى - } \\
& \text { رويم بر مقدار فراوانى خشكسالى هاى شديد و متوسـط و همجنسين } \\
& \text { ترسالى هاى شديد و فرين افزوده مىشود. از ديدگاه شاخص SPEI } \\
& \text { در بازههاى كوتاهمدت خشكسالى متوسط و شديد و ترسالى شـديد } \\
& \text { افزايش نشان داده و هر جهه بهسمت بـازههـاى بلندمــت مسىرويـم } \\
& \text { خشكسالى شديد داراى فراوانى بيشتر شده و همجنين ترسالىهـاى } \\
& \text { فرين افزايش مىيابند. در ايستخاه باغ كوثر (كـم ارتفـاعتـرين) و در } \\
& \text { شمال شرق منطقــه از ديــدكاه شـاخص SPI در بــازه كوتـاهمــات }
\end{aligned}
$$

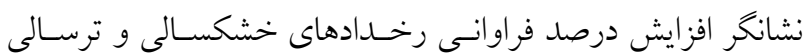

$$
\begin{aligned}
& \text { شديد و فرين بوده و هرجه بمسمت بازههاى بلندمدت مسىرود بـر } \\
& \text { فراوانى رخدادهاى حدى خشكسالى و ترسالى افزوده مسىشـود. از }
\end{aligned}
$$

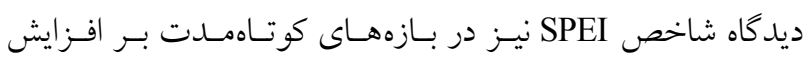

\section{منابع مورد استفاده}

1. Ababaei, B., T. Sohrabi, F. Mirzaei, V. R. Verdinejad and B. Karimi. 2010. Climate change impact on wheat yield and analysis of the related risks: (Case Study: Esfahan Ruddasht region). Journal of Water and Soil Science 20(3): 135-150. (In Farsi).

2. Babaeian, A. and M. Kouhi. 2012. Agroclimatic indices assessment over some selected weather stations of Khorasan Razavi province under climate change scenarios. Journal of Water and Soil 26(4): 953-967. (In Farsi).

3. Banihashemi, S. M., S. S. Eslamian and B. Nazari. 2020. The impact of climate change on wheat, barley, and maize growth indices in near-future and far-future periods in Qazvin plain, Iran. International Journal of Plant Production 15(1): 45-60. (In Farsi).

4. Bazrafshan, O., F. Mahmudzadeh and J. Bazrafshan. 2017. Evaluation of temporal trends of the SPI and SPEI drought indices in the Southern Coast of Iran. Desert Management 8: 54-69. (In Farsi).

5. Bocchiola, D., E. Nana and A. Soncini. 2013. Impact of climate change scenarios on crop yield and water footprint of maize in the Po Valley of Italy. Journal of Agricultural Water Management 116: 50-61.

6. Chen, X., L. Wang, Z. Niu, M. Zhang, C. Li and J. Li. 2020. The effects of projected climate change and extreme climate on maize and rice in the Yangtze River Basin, China. Agricultural and Forest Meteorology 282-283: 1-14.

7. Daneshfaraz, R. and H. Razzaghpour. 2014. Evaluation of climate change impacts on potential evapotranspiration in the West Azerbaijan province. Journal of Geographical Space 14(46): 199-211. (In Farsi).

8. Eghtedar Nezhad, M., O. Bazrafshan and J. Bazrafshan. 2017. Spatio-temporal variations of meteorological drought using Standardized Precipitation Evapotranspiration Index in Iran. Journal of Agricultural Meteorology 5(2): 35-46. (In Farsi). 
9. Estrella, N. and A. Menzel. 2013. Recent and future climate extremes rising from changes to the bivariate distribution of temperature and precipitation in Bavaria, Germany. Journal of Climatology 33: 1687-1695.

10. Gohari, A., S. Eslamian, J. Abedi-Koupaei, A. Massah Bavani, D. Wang and K. Madani. 2013. Climate change impacts on crop production in Iran's Zayandeh-Rud river basin. Journal of Science of the Total Environment 442: 405-419.

11. He, L., N. Jin and Q. Yu. 2020. Impacts of climate change and crop management practices on soybean phenology changes in China. Science of the Total Environment 707: 1-11.

12. Hejazi Zade, Z., E. Fattahi and H. Ghaemi. 2002. Drought monitoring by using the standardized percipitation index, Case study: Chaharmahal Bakhtiari province. Journal of Applied Researches in Geographical Sciences 1: 23-45. (In Farsi).

13. IPCC. 2007. Climate Change 2007. Cambridge University Press, New York.

14. Koochaki, A., M. Nassiri Mahallati and L. Jafari. 2016. Evaluation of climate change effect on agricultural production of Iran: I. predicting the future agroclimatic conditions. Iranian Journal of Field Crop Research 13(4): 651-664. (In Farsi).

15. Li, G. Q., S. P. Harrison, P. J. Bartlein, K. Izumi and I. C. Prentice. 2013. Precipitation scaling with temperature in warm and cold climates: an analysis of CMIP5 simulations. Journal of Geophysical Research Letters 40: 40184024.

16. López-Moreno, J. I., S. M. Vicente-Serrano, E. Morán-Tejeda, J. Lorenzo-Lacruz, A. Kenawy and M. Beniston. 2011. Effects of the North Atlantic Oscillation (NAO) on combined temperature and precipitation winter modes in the Mediterranean mountains: observed relationships and projections for the 21st century. Journal of Global and Planetary Change 77: 62-76.

17. Mavromatis, T. and J. Hansen. 2001. Interannual variability characteristics and simulated crop response of four stochastic weather generators. Journal of Agriculture and Forest Meteorology Research 109: 283-296.

18. Mckee, T. B., N. J. Doesken and J. Kleist. 1993. The relationship of drought frequency and duration to time scales. In: Proceedings of the Eighth Conference on Applied Climatology, American Meteorological Society, Anaheim, California: 179-184.

19. Mostafazadeh, R. and M. Zabihi. 2016. Comparison of SPI and SPEI indices to meteorological drought assessment using R programming (Case study: Kurdistan Province). Journal of the Earth and Space Physics 42(3): 632-643. (In Farsi).

20. Palazzoli, I., S. Maskey, S. Uhlenbrook, E. Nana and D. Bocchiola. 2015. Impact of prospective climate change on water resources and crop yields in the Indrawati Basin, Nepal. Journal of Agricultural Systems 133: 143-157.

21. Semenov, M. and P. Stratonovitch. 2010. Use of multi-model ensembles from global climate models for assessment of climate change impacts. Journal of Climate Research 41: 1-14.

22. Semenov, M. 2007. Development of high-resolution UKCIP02-based climate change scenarios in the UK. Journal of Agriculture and Forest Meteorology Research 144: 127-138.

23. Semenov, M. and E. Barrow. 1997. Use of a stochastic weather generator in the development of climate change scenarios. Journal of Climate Change 35: 397-414.

24. Sun, S., P. Wu, Y. Wang, X. Zhao, J. Liu and X. Zhang. 2013. The impacts of interannual climate variability and agricultural inputs on water footprint of crop production in an irrigation district of China. Journal of Science of the Total Environment 444(2): 498-507.

25. Sun, S. K., Y. B. Wang, J. Liu, H. J. Cai, P. T. Wu, L. J. Xu and Q. L. Geng. 2016a. Sustainability assessment of regional water resources under the DPSIR framework. Journal of Hydrology 532: 140-148.

26. Trenberth, K. E. 2011. Changes in precipitation with climate change. Journal of Climate Research 47: $123-138$.

27. Trigo, R. and J. Palutikof. 2001. Precipitation Scenarios over Iberia: a Comparison between Direct GCM Output and different downscaling techniques. Journal of Climate 14: 4422-4446.

28. Vicente-Serrano, S. M., S. Beguería and J. I. López-Moreno. 2010. A multiscalar drought index sensitive to global warming: the standardized precipitation evapotranspiration index. Journal of Climate 23(7): 1696-1718.

29. Yaghmaei, L., S. Soltani, R. Jafari, H. Bashari and H. Jahanbazi. 2017. An investigation on impact of drought on rangeland and forest vegetation changes in Chaharmahal \& Bakhtiari province using MODIS satellite dat. Iranian Journal of Forest and Range Protection Research 15(1): 91-108. (In Farsi).

30. Zareian, M. J., S. S. Eslamian and H. R. Safavi. 2016. Investigating the effects of sustainability of climate change on the agriculture water consumption in the Zayandeh-Rud River basin. Journal of Water and Soil Science (Science and Technology of Agriculture and Natural Resources) 75(20): 113-128. (In Farsi).

31. Zhang, X., X. Du, J. Hong, Z. Du, X. Lu and X. Wang. 2020. Effects of climate change on the growing season of alpine grassland in Northern Tibet, China. Global Ecology and Conservation 23: 1-12. 


\title{
Prediction of Local Alterations in the Relative Amounts of Temperature and Precipitation Caused by Climate Change in Near and Far Future, and Drought Investigation Using SPI and SPEI Indices in Qazvin Plain, Iran
}

\author{
M. Banihashemi ${ }^{1}$, S. S. Eslamian ${ }^{1}$ and B. Nazari ${ }^{2}$
}

(Received: July 6-2020; Accepted: July 28-2020)

\begin{abstract}
The upcoming climate change has become a serious concern for the human society. These changes, caused and aggravated by the industrial activities of the international community and the increase in the concentration of greenhouse gases in the atmosphere, are seen as a threat to the food security and environment. Temperature change and precipitation are studied in the form of different probabilistic scenarios in order to have an outlook for the future. The present study was conducted to address the effects of climate changes on temperature and precipitation in Qazvin plain in the form of five AOGCMs including Hadcm3, CSIRO-MK3, GFDL, CGCM3 and MICROC3.2, and 3 greenhouse gas emission scenarios of A1B, A2 and B1, based on different possible scenario combinations in the next 30 years, 2021-2050 and 2051-2080 (near and far future). On basis of the study results, all 4 target stations, on average, will have experienced a change between two ratios of 0.5 and 1.4 of the observed precipitation period by the end of 2050 , and the mean temperature will have had a change between -0.1 to $1.6{ }^{\circ} \mathrm{C}$, relative to the observed period. By the end of 2080, the precipitation will also have fluctuated between the two proportions of 0.5 and 1.7 times of the observed precipitation period and the mean temperature will touch an increase between 0.6 and $2.6{ }^{\circ} \mathrm{C}$. Both SPI and SPEI indices suggest the increment in the number of dry periods in the near and far future. However, the total number of negative sequences differed considering the 3,12 and 24-month intervals at the stations level. Given the SPEI index, as compared to the base period, the total negative sequences of drought and number of dry periods will increase at 3 stations of Avaj, Bagh-Kowsar and Shahid-rajaei-powerhouse and decrease at Qazvin station in the future; however, SPI gives different results, such that for Bagh-Kowsar, there will be an increase in both total negative sequences of drought and number of dry periods, as compared to the baseline period; three other stations will have more dry periods, specifically, but less total negative sequences. The results reported that the drought events would become severe, and the wet events would become extreme in the future.
\end{abstract}

Keywords: Climate Change, Qazvin Plain, Temperature, Precipitation, drought, Standardized Precipitation Index (SPI), Standardized Precipitation Evapotranspiration Index (SPEI).

1. Department of Water Engineering, College of Agriculture, Isfahan University of Technology, Isfahan, Iran.

2. Department of Water Sciences and Engineering, Faculty of Agriculture \& Natural Resourses, Imam Khomeini International University, Qazvin, Iran.

Corresponding author, Email: m.banihashemi@ut.ac.ir 